Life Sciences Contributions 77
Royal Ontario Museum

Population Studies of Myotis lucifugus (Chiroptera: Vespertilionidae) in Ontario

M. Brock Fenton

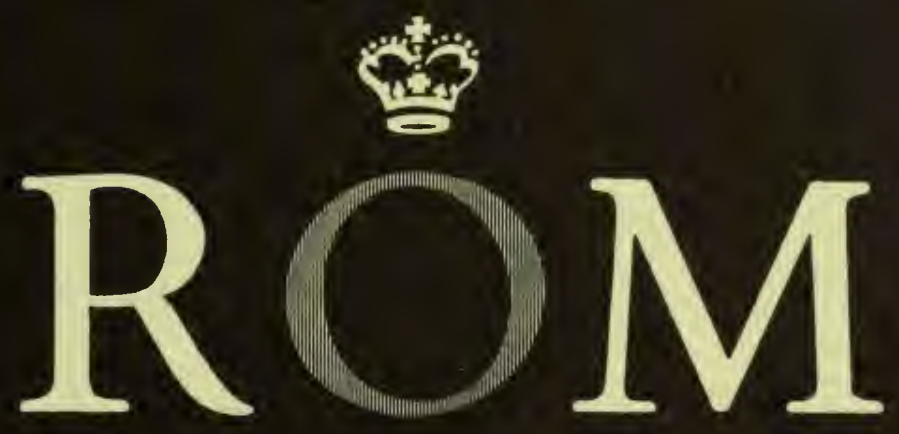



LIFE SCIENCES CONTRIBUTIONS

ROYAL ONTARIO MUSEUM

NUMBER 77

M. BROCK FENTON Population Studies of

Myotis lucifugus

(Chiroptera: Vespertilionidae) in Ontario

Publication date: 17 August 1970

Suggested citation: Life Sci. Contr., R. Ont. Mus. 


\section{ROYAL ONTARIO MUSEUM PUBLICATIONS IN LIFE SCIENCES}

The Royal Ontario Museum publishes three series in the Life Sciences:

LIFE SCIENCES CONTRIBUTIONS, a numbered series of original scientific publications, including monographic works.

LIFE SCIENCES OCCASIONAL PAPERS, a numbered series of original scientific publications, primarily short and usually of taxonomic significance.

LIFE SCIENCES MISCELLANEOUS PUBLICATIONS, an unnumbered series of publications of varied subject matter and format.

All manuscripts considered for publication are subject to the scrutiny and editorial policies of the Life Sciences Editorial Board, and to review by persons outside the Museum staff who are authorities in the particular field involved.

LIFE SCIENCES EDITORIAL BOARD, 1969

Chairman: P. C. SWANN

Director, Royal Ontario Museum

Editors: R. L. PETERSON

E. J. CROSSMAN

M. BRock FEnton, Assistant Professor of Biology, Carleton University, Ottawa, is a Research Associate in the Department of Mammalogy, Royal Ontario Museum.

PRICE : \$2.00

(C)The Royal Ontario Museum, 1970

100 Queen's Park, Toronto, Canada

PRINTED BY THE UNIVERSITY OF TORONTO PRESS 


\section{Contents}

Abstract, 1

Introduction, 1

Study Area, 2

Methods, 2

Observations and Results, 4

Parturition, 4

Variation of Winter Weights, 6

Movements, 8

Environment of Roosts, 12

Population Studies, 16

Discussion, 22

Temperature and Humidity of Hibernacula, 22

Clustering of Hibernating Bats, 22

Hibernation, 23

Heterothermy, 25

The Effect of Man, 26

Acknowledgments, 27

Literature Cited, 28 
Digitized by the Internet Archive in 2011 with funding from University of Toronto 


\title{
Population Studies of
}

\section{Myotis lucifugus \\ (Chiroptera: Vespertilionidae) in Ontario}

\begin{abstract}
This study was carried out in hibernacula and diurnal roosts in Ontario and adjacent Quebec and New York State. In southeastern Ontario in 1966, female Myotis lucifugus (Le Conte) gave birth to young between 7 June and 5 July. Banded bats travelled up to 160 miles between summer and winter roosts and moved between various hibernacula and summer colonies. $M$. lucifugus hibernated in areas where the temperature did not go below freezing and air movement was minimal. In winter, adult females weighed significantly more than adult males; both sexes lost weight continuously during hibernation. Moreover, disturbance of hibernating $M$. lucifugus increased the rate of weight loss. Data from weights suggested that clustering of hibernating $M$. lucifugus retarded pulmocutaneous loss of water. Subfreezing temperatures probably caused arousal and emigration of hibernating $M$. lucifugus from exposed regions of the hibernacula; arousals in unexposed areas are thought to be related to the water economy (thirst or the need to urinate). Bats in nursery colonies formed clusters to maintain high body temperatures and did not enter torpor; those in diurnal shelters regularly became torpid at lower temperatures. Heterothermy in bats is considered to be a specialized condition rather than merely poor thermoregulation. A predominance of male $M$. lucifugus was observed in hibernating populations. Man has facilitated an increase in the bat population by providing more roosting sites that bats have been quick to locate and exploit. Availability of roosts, rather than predation, is an important factor limiting bat populations in Ontario.
\end{abstract}

\section{Introduction}

Between 1965 and 1969, studies of the biology of Myotis lucifugus lucifugus (LeConte), 1831, the little brown myotis, were carried out in Ontario and adjacent parts of Quebec and New York State. Data in this paper cover parturition, loss of weight in winter, hibernation, habitat selection, seasonal movements and populations of this species. 
M. lucifugus, one of nine vespertilionid bats reported in Ontario (Peterson, 1966), is the commonest local species. In this region bats reach the northern limit of their distribution and a study of the life history of marginal populations is of particular interest.

Most vespertilionids mate in the autumn and the sperm are stored over winter in the uterus of the female (Brosset, 1966). Ovulation and fertilization occur in the spring when the female arouses from hibernation. Growth of young bats is both rapid and markedly allometric. Jones (1967), Davis et al. (1968) and Kleiman (1969) reported that different vespertilionid bats could fly three weeks after birth. The thumbs and hind feet of the neonate are large, allowing it to cling to its mother (Fenton, 1966a), but show little subsequent growth. Structures relating to flight (bones supporting the wing) increase greatly. Flight occurs when the wing area of the juvenile bat is large enough to support the body weight (Jones, 1967). Female $M$. lucifugus do not appear to carry their young while feeding, but will transport them from one roost to another (Fenton 1969a).

$M$. lucifugus hibernates locally in caves and mines and upon arousing from hibernation, females occupy nursery colonies that are usually situated in attics. Nursery colonies rarely contain adult males. After departing from the nursery colonies in late July, females and young appear with adult males in nocturnal flights through hibernacula (referred to as "swarming," Fenton, $1969 \mathrm{~b})$. This phenomenon involves the selection of suitable hibernation sites, dispersal, prenuptial meetings and a prelude to migration (Fenton, 1969b). Hibernating populations appear in the hibernacula in early September and have usually departed from these sites by the end of April.

\section{Study Area}

Hibernacula and summer colonies studied were located between 43 and $50^{\circ} \mathrm{N}$ and 75 and $90^{\circ} \mathrm{W}$ (Figure 1). Areas between the indicated sites were not investigated. Research in the summer months was concentrated in the vicinity of Chaffey's Locks, north of Kingston, Ontario, although I also visited colonies in different parts of southern Ontario. In the winter, most of the work was done at the Renfrew mine (Figure 1, number 11), but caves and mines in other parts of Ontario, Quebec and northern New York State were also studied. Caves occur in the limestone beds of the Ottawa and St. Lawrence River Valleys and occasionally in the metamorphosed limestones of the Canadian (Precambrian) shield.

Data concerning dates of parturition were obtained from nursery colonies at the following localities in Ontario: Chaffey's Locks, Lyndhurst, Seeley's Bay, and Westport (two colonies) in Leeds County, Mountain Grove and Tichborne in Frontenac County and Glenora in Prince Edward County and West Huntingdon in Hastings County.

\section{Methods}

The study is based primarily on field investigations of $M$. lucifugus and the environment of its roosts under as nearly natural conditions as possible. 


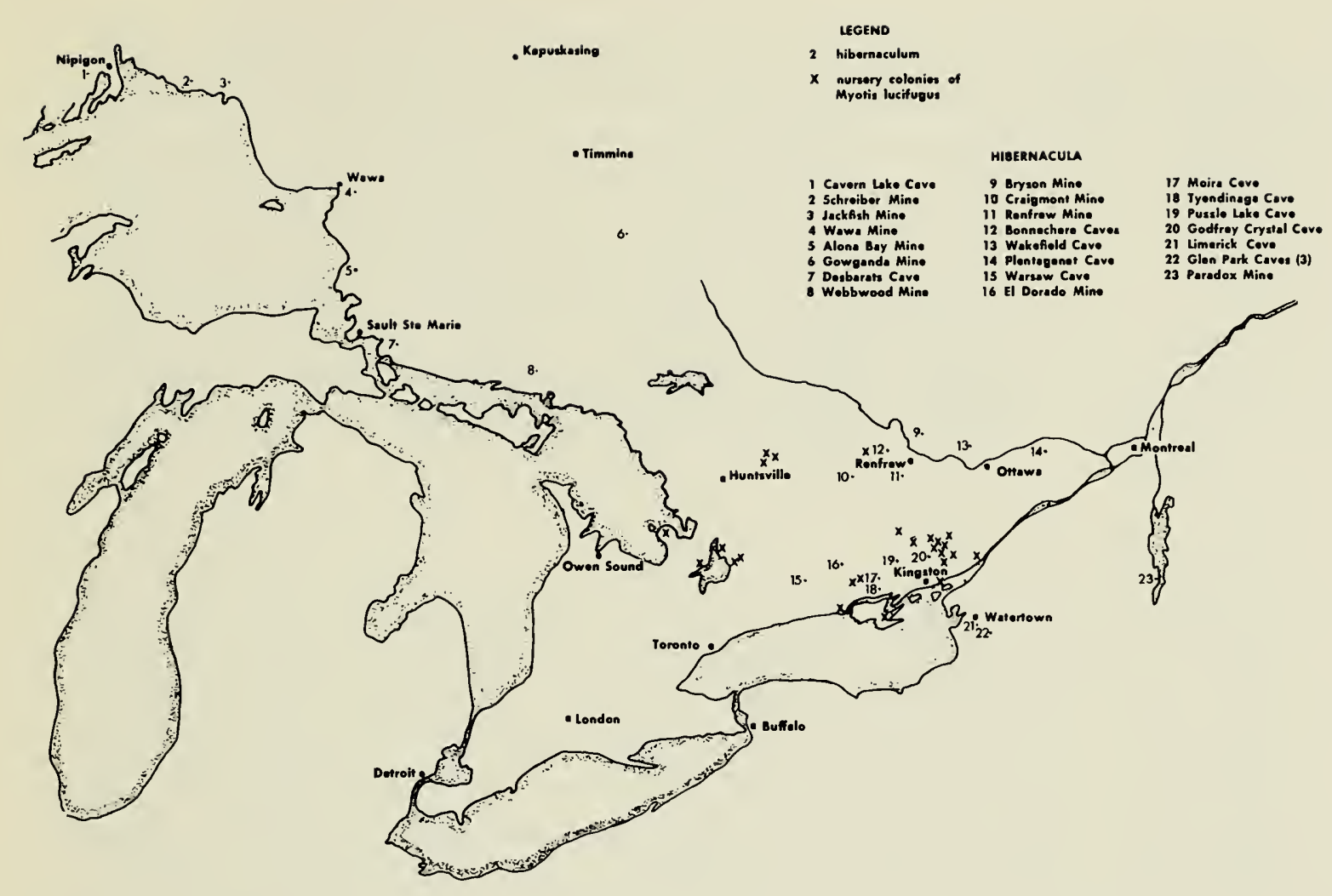

Fig. 1-The distribution of hibernacula and nursery colonies of Myotis lucifugus in the study area.

During the summer I obtained bats from nursery colonies where they were captured by hand or removed with long forceps or driven from the recesses with tobacco smoke. If I could not enter the roost, the bats were caught as they departed, either in mist nets or in cheese cloth funnels attached to Hitchcock cages (Greenhall and Paradiso, 1968). In the winter torpid bats hung from the ceilings of hibernacula and were easily obtained. Bats hibernating in drill holes or crevices were extracted using long forceps or soft wire on the end of a long stick.

Bats were banded using bands supplied by the United States Fish and Wildlife Service. Bands were placed on the right forearm without piercing the patagium. Species, sex and location and date of banding were recorded for each band number. I started banding bats in December 1963 and continue to do so at present. Through television, radio and displays, I attempted to familiarize the public with the project in an effort to increase band returns.

Weights accurate to 0.1 grams were obtained from samples of $25 \mathrm{M}$. lucifugus using an Ohaus triple beam balance with cage attached which allowed the bats to be weighed alive. Weights of bats were taken on each visit to summer colonies and the Renfrew mine. Only hibernating bats without water droplets on their fur were weighed, but on two occasions wet bats (those with water droplets in their fur) were dried with paper towel before they were weighed. Regression analyses and Student-Fischer "T" Tests were applied to the weight data. 
The temperatures of summer and winter bat roosts were obtained with recording (Bacharach Tempscribe) and maximum-minimum (Taylor and Sci-Bor) thermometers. Humidity was measured with a hair hygrometer. Environmental data were obtained from the Renfrew mine in the winters of 1965-66 through 1967-68 and from the Bryson mine in the winter of 1967-68. Nursery colonies were studied during the summer of 1966 at Mountain Grove, Chaffey's Locks and Westport. Temperatures in the spaces behind window shutters at the Queen's University Biological Station near Chaffey's Locks were taken in the summer of 1967.

\section{Observations and Results}

\section{PARTURITION}

Dates of parturition for $M$. lucifugus were 17 May to 20 July in Carbondale, Illinois (Cagle and Cockrum, 1943), the end of June to early July in Ithaca, New York (Wimsatt, 1945), from 7 June to 17 July in northeastern Ohio (Smith, 1954), 23 May to 14 July at Newcomb, near New York City (Stegeman, 1954) and from 20 May to 10 June at Schoharie, New York (Benton and Scharoun, 1958). Birth first occurred on 7 June near Middlebury, Vermont (Davis and Hitchcock, 1965). Generally, parturition occurs earlier in more southern locales, but dates of first parturition from neighbouring locations do not coincide ( $c f$. Schoharie, Ithaca, Newcomb and Middlebury).

Neonates were first observed on 7 June in 1965 and 1966 at colonies in Chaffey's Locks and Westport. This corresponds to the time when they were first observed in 1964 (9 June) at Chaffey's Locks. At both Chaffey's Locks and Westport nursery colonies, juveniles were not seen on 5 and 6 June in 1965 and 1966 and parturition probably did not occur before 7 June 1965 and 1966.

Increasing range in the weights of females from samples between 24 May and 29 June 1966 (Fig. 2) is correlated with parturition. The great range of weight observed in the latter part of June was because of the discrepancy between weights of pre- and post-partum females. By 5 July 1966, most of the females had given birth, causing a sharp decrease in the variation of weight.

Dates when young first appeared in the nursery colonies (indicators of first parturition) are considered with the reduction in the range of weight of the adult females (indicator of last parturition), and parturition is deduced to have occurred between 7 June and 5 July.

Eisentraut (1936) indicated that the date of parturition may depend upon the time when the bat left hibernation, which is in turn related to the weather. Racey (1969) showed that the gestation period of Pipistrellus pipistrellus may be prolonged by the induction of torpor during pregnancy. The earlier dates of parturition in southern Illinois (Cagle and Cockrum, 1943) support this. However, near Chaffey's Locks between 10 and 20 May, temperatures in 1966 were as much as $8 \mathrm{C}^{\circ}$ colder than in 1965 and parturition occurred at the same time. 


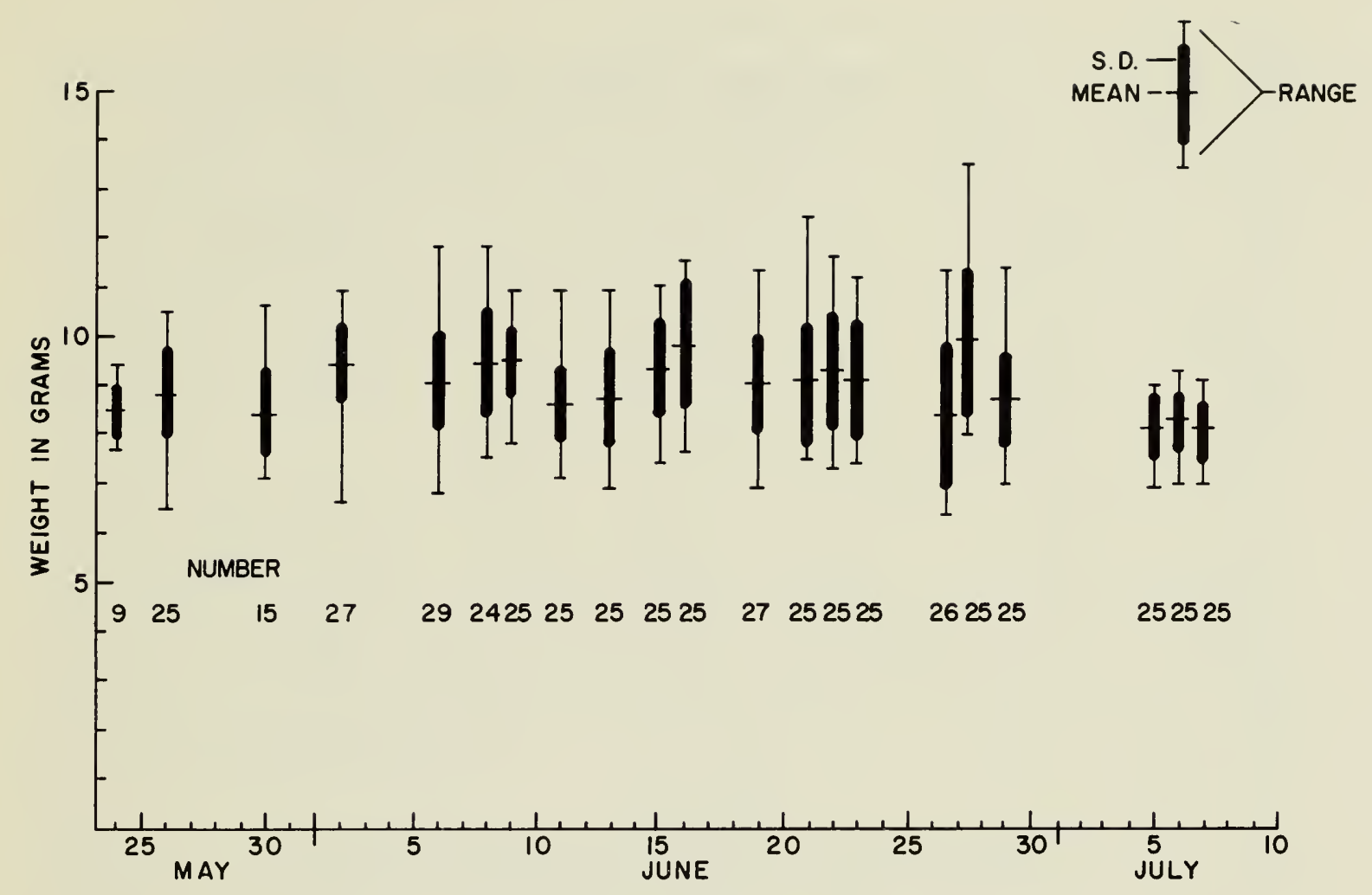

Fig. 2-Variation in the weight of female Myotis lucifugus.

The dates of the parturition period, or the time of first parturition given by other authors were calculated in different ways. Wimsatt (1945) used the occurrence of foetuses in different stages of development to establish dates of parturition for the area around Ithaca, New York. Smith (1954) did not mention how her parturition dates were derived. Cagle and Cockrum (1943) and Davis and Hitchcock (1965) based their dates of parturition on the actual observation of young in nursery colonies. Stegeman (1954) calculated the period of parturition by assuming a constant growth rate for the forearm of juvenile M. lucifugus based on Sherman's (1930) data for Myotis austroriparius. Benton and Scharoun (1958) also used this method to extrapolate the age of young and dates of birth. But Stegeman (op. cit.) assumed that the forearm of a new born $M$. lucifugus was 10.0 millimetres long. I found the average length of forearm for eight new born $M$. lucifugus to be $13.2 \mathrm{~mm}$ with the smallest only $11.8 \mathrm{~mm}$. According to Stegeman's (op. cit.) application of Sherman's (op. cit.) growth rate, juvenile $M$. lucifugus would not be volant until age 50 days. I saw volant juveniles three weeks after the first parturition date.

Because of the discrepancies both in size of forearm and in rate of growth of juvenile $M$. lucifugus, the parturition dates given by Stegeman (1954) and Benton and Scharoun (1958) are probably incorrect. Parturition dates established by direct observation correspond for Ontario and Middlebury, Vermont (Davis and Hitchcock, 1965). Discrepancies between dates of parturition for $M$. lucifugus are undoubtedly caused by differences in methods used to determine these dates and probably do not reflect the actual situation. 
VARIATION OF WINTER WEIGHTS

Although data are available for loss of weight in winter of Eptesicus fuscus, the big brown bat (Beer and Richards, 1956), comparable data for $M$. lucifugus have been lacking. I obtained the following data from hibernating bats at the Renfrew mine during the winters of 1965-66 through 1967-68.

The average weight of $M$. lucifugus hibernating in the Renfrew mine during the winter of 1966-67 decreased from 10.0 grams in October to 7.5 grams in April ( $N=50$ for both samples; 25 males and 25 females). This is a decrease in weight of 2.5 grams during a 193-day period and represents a loss of $25 \%$ of the October body weight.

Throughout the winter females weighed significantly more than males (Table I), but the rate of loss of weight was the same for both sexes ( 0.013 grams per day). A comparison of the forearm sizes of 50 male and 50 female $M$. lucifugus indicated that females averaged slightly $(0.5 \mathrm{~mm})$ larger. A linear regression analysis indicated a significant inverse relationship between weight loss and the passage of time for this species for males and females $(0.001<p<0.01 ;$ Fig. 3$)$.

Bats hibernating alone (not in physical contact with other bats) weighed less than those hibernating in clusters, particularly in March and April (Table II). The weights of wet (covered with water droplets before they were dried off and weighed) and dry lone bats of both sexes were compared. On 17 February 1968, 21 dry males weighed significantly less than six wet individuals ( $p=0.01: 7.3 \pm 0.5$ and $8.1 \pm 0.5$ grams respectively). On 23 March 1968, the weights of 26 dry and 18 wet bats did not differ significantly. At that time the dry individuals averaged $7.3 \pm 0.6$ and the wet ones $7.1 \pm 0.7$ grams.

Weights of bats known to be juveniles on 23 September 1968 were com-

TABLE I

Weights of male and female Myotis lucifugus from the Renfrew mine $(\mathbf{N}=25)$

\begin{tabular}{|c|c|c|c|c|c|}
\hline \multirow[b]{2}{*}{ Date } & \multicolumn{2}{|c|}{ Males } & \multicolumn{2}{|c|}{ Females } & \multirow[b]{2}{*}{$t$} \\
\hline & $\overline{\mathbf{X}}$ & SD & $\overline{\mathbf{X}}$ & SD & \\
\hline 2.X.66 & 9.8 & 0.6 & 10.3 & 0.9 & $2.29^{*}$ \\
\hline 5.XI.66 & 8.6 & 0.6 & 9.4 & 0.9 & $3.67^{* * *}$ \\
\hline 2.XII.66 & 8.3 & 0.6 & 8.9 & 0.9 & $2.76^{* *}$ \\
\hline 14.I.67 & 7.8 & 0.4 & 8.1 & 0.7 & $1.83^{*}$ \\
\hline 11.II.67 & 7.6 & 0.4 & 8.4 & 0.7 & $4.40^{* * *}$ \\
\hline 10.IV.67 & 7.2 & 0.5 & 7.8 & 0.5 & $4.20 * * *$ \\
\hline 30.XI.67 & 8.8 & 0.5 & 9.1 & 0.8 & NS \\
\hline \multirow[t]{2}{*}{ 27.I.68 } & c 8.2 & 0.6 & 8.6 & 0.7 & $2.23^{*}$ \\
\hline & s 8.0 & 0.6 & 8.6 & 0.7 & $3.11^{* *}$ \\
\hline 17.II. 68 & 7.5 & 0.6 & 8.0 & 0.7 & $2.16^{*}$ \\
\hline \multirow{2}{*}{\multicolumn{3}{|c|}{$\begin{array}{l}\overline{\mathrm{X}}-\text { mean weight in grams } \\
\mathrm{SD}-\text { standard deviation in grams } \\
t-\text { value of Student-Fischer "T" } \\
*-0.01<\mathrm{p}<0.05 \\
* *-0.001<\mathrm{p}<0.01\end{array}$}} & \multirow{2}{*}{\multicolumn{2}{|c|}{$\begin{array}{l}* * *-p>0.001 \\
\text { NS-not significant } \\
\text { c-from cluster } \\
\text { s-solitary }\end{array}$}} & \\
\hline & & & & & \\
\hline
\end{tabular}


TABLE II

Weights of Myotis lucifugus hibernating alone and in clusters (see Table $I$ for symbols)

\begin{tabular}{|c|c|c|c|c|c|c|}
\hline \multirow[b]{2}{*}{ Date } & \multirow[b]{2}{*}{ Sex } & \multicolumn{2}{|c|}{ Clusters } & \multicolumn{2}{|c|}{ Alone } & \multirow[b]{2}{*}{$t$} \\
\hline & & $\overline{\mathrm{X}}$ & SD & $\overline{\mathrm{X}}$ & SD & \\
\hline 14.I.67 & M & 8.0 & 0.4 & 7.7 & 0.7 & NS \\
\hline 11.II.67 & $\mathbf{M}$ & 7.8 & 0.7 & 7.5 & 0.8 & NS \\
\hline 4.III.67 & $\mathbf{M}$ & 7.6 & 0.5 & 7.1 & 0.5 & $3.50 * *$ \\
\hline 10.IV.67 & $\mathbf{M}$ & 7.4 & 0.4 & 7.0 & 0.4 & $4.00^{* * *}$ \\
\hline \multirow[t]{2}{*}{$30 . X I .67$} & $\mathbf{M}$ & 8.8 & 0.5 & $8.6(15)^{1}$ & 0.4 & NS \\
\hline & $\mathrm{F}$ & 9.1 & 0.8 & $8.7(9)^{1}$ & 0.6 & NS \\
\hline \multirow[t]{2}{*}{ 27.I.68 } & $\mathbf{M}$ & 8.2 & 0.6 & 8.0 & 0.6 & NS \\
\hline & F & 8.6 & 0.6 & 8.6 & 0.7 & NS \\
\hline \multirow[t]{2}{*}{ 17.II.68 } & $\mathbf{M}$ & 7.5 & 0.6 & $7.2(15)^{1}$ & 0.5 & NS \\
\hline & $\mathrm{F}$ & 7.9 & 0.7 & $7.5(6)^{1}$ & 0.4 & NS \\
\hline 23.III.68 & $\mathbf{M}$ & 7.6 & 0.5 & 7.2 & 0.5 & $2.38^{*}$ \\
\hline
\end{tabular}

${ }^{1}$ Sample size if less than 25.

\section{TABLE III}

Weights of Myotis lucifugus from northern hibernacula and from the Renfrew mine 1

(see Table I for symbols)

\begin{tabular}{|c|c|c|c|c|c|c|c|c|}
\hline \multirow[b]{2}{*}{ Location } & \multirow[b]{2}{*}{ Sex } & \multirow[b]{2}{*}{$\mathbf{N}$} & \multirow[b]{2}{*}{$\overline{\mathbf{X}}$} & \multirow[b]{2}{*}{ SD } & \multicolumn{4}{|c|}{ Renfrew Mine } \\
\hline & & & & & $\mathrm{N}$ & $\overline{\mathrm{X}}$ & SD & $t$ \\
\hline Gowganda & $\mathbf{M}$ & 15 & 9.0 & 0.8 & 25 & 9.8 & 0.6 & $3.6^{* * *}$ \\
\hline Webbwood & $\mathbf{M}$ & 18 & 9.2 & 0.4 & 25 & 9.8 & 0.6 & $3.6^{* * *}$ \\
\hline Schreiber & $\mathbf{M}$ & 15 & 9.9 & 0.7 & 25 & 9.8 & 0.6 & NS \\
\hline Gowganda & $\mathbf{F}$ & 15 & 10.1 & 1.1 & 25 & 10.3 & 0.6 & NS \\
\hline Webbwood & $\mathrm{F}$ & 15 & 9.8 & 1.0 & 25 & 10.3 & 0.6 & NS \\
\hline Schreiber & $\mathrm{F}$ & 15 & 10.7 & 0.9 & 25 & 10.3 & 0.6 & NS \\
\hline
\end{tabular}

$\mathrm{N}$-sample size

1The data from the northern sites were obtained at Gowganda on 20 October 1967, at Webbwood on 21 October 1967 and at Schreiber on 24 October 1967. Weights were obtained from the Renfrew mine on 2 October 1966.

TABLE IV

Effect of disturbance on the weights of hibernating male Myotis lucifugus $(N=25)$ (refer to Table I for symbols)

\begin{tabular}{lccccccl}
\hline \hline Date & $\begin{array}{c}\text { Times } \\
\text { caught }\end{array}$ & $\overline{\mathrm{X}}$ & SD & $\begin{array}{c}\text { Times } \\
\text { caught }\end{array}$ & $\overline{\mathrm{X}}$ & SD & \multicolumn{1}{c}{$t$} \\
\hline 28.XII.65 & 1 & 8.4 & 0.6 & 2 & 8.0 & 0.5 & NS \\
28.XII.65 & 1 & 8.4 & 0.6 & 3 & 7.8 & 0.4 & $4.10^{* * *}$ \\
28.XII.65 & 2 & 8.0 & 0.5 & 3 & 7.8 & 0.4 & NS \\
15.II.66 & 1 & 8.0 & 0.4 & 2 & 7.7 & 0.4 & NS \\
15.II.66 & 1 & 8.0 & 0.4 & 3 & 7.5 & 0.5 & $3.69^{* * *}$ \\
15.II.66 & 2 & 7.7 & 0.4 & 3 & 7.5 & 0.5 & NS \\
26.III.66 & 1 & 7.5 & 0.6 & 2 & 7.4 & 0.5 & NS \\
26.III.66 & 1 & 7.5 & 0.6 & 3 & 7.1 & 0.5 & $3.38^{* * *}$ \\
26.III.66 & 2 & 7.4 & 0.5 & 3 & 7.1 & 0.5 & $2.18^{*}$ \\
\hline
\end{tabular}


pared with the weights of known adults from the same date. The mean weight of 13 juveniles was $9.7 \pm 0.5$ grams and $10.3 \pm 0.6$ grams in 23 known adults, a difference of 0.6 grams (significant at the 0.01 level). The juveniles do not have as much time to accumulate weight as do the adults and they may be less efficient at catching prey (Gould, 1955). Such weight differences may be a significant factor in the survival of juvenile bats during their first winter (Davis and Hitchcock, 1965 and Davis, 1966).

Although bats from northern Ontario might be expected to weigh less than their southern counterparts because of a shorter season, weights of bats from northern and southern hibernacula show no consistent significant differences (Table III).

The more frequently that hibernating $M$. lucifugus were disturbed, the less they weighed (Table IV). Bats disturbed at least three times weighed significantly less than those disturbed once. Disturbance was caused by handling the bats for banding, reading of the band number, weighing and removing the bat from where it was found to another location within the Renfrew mine. Mumford (1958) found that disturbance did not increase weight loss, but admitted that his sample size was inadequate.

Hibernating $M$. lucifugus consistently lost weight during the winter period. An examination of the weight records of 31 marked $M$. lucifugus from the winters of 1965-66 and 1966-67 indicated that bats did not increase weight between monthly readings.

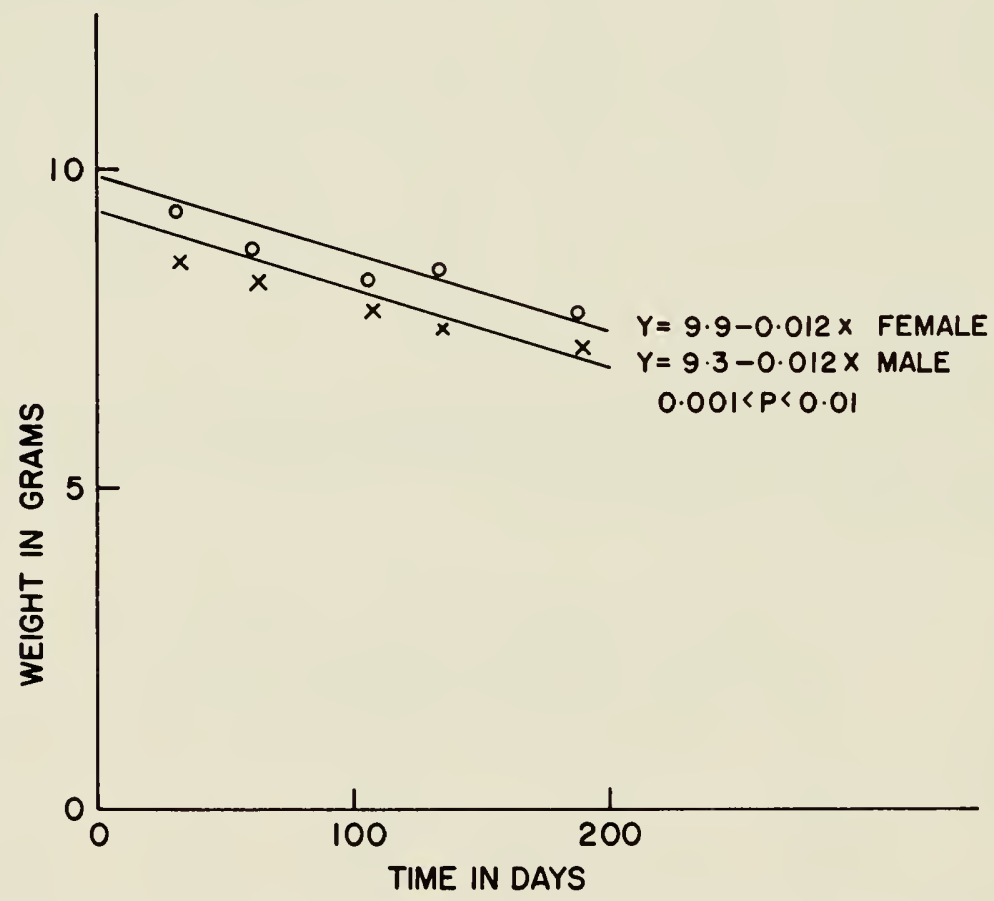

Fig. 3-Regression of weight change on length of time in hibernation for Myotis lucifugus from the winter of 1966-67.

\section{MOVEMENTS}

Davis and Hitchcock (1965) described migrations of M. lucifugus in New England and found that bats regularly move at least 150 miles to nursery colonies southeast from a hibernaculum in Vermont. Griffin (1940 and 1945), Gifford and Griffin (1960) and Humphrey and Cope (1964) also 
report seasonal movements of this species. Hitchcock (1965) lists several seasonal movements for $M$. lucifugus in Ontario. Three of these were from the Craigmont mine to sites 70 miles southwest, 82 miles south and five miles north. Another was from Tyendinaga cave to the south-southwest.

Seasonal movements determined by band recoveries in Ontario are shown in Figures 4 and 5. Movements from the Renfrew mine (Fig. 4) were

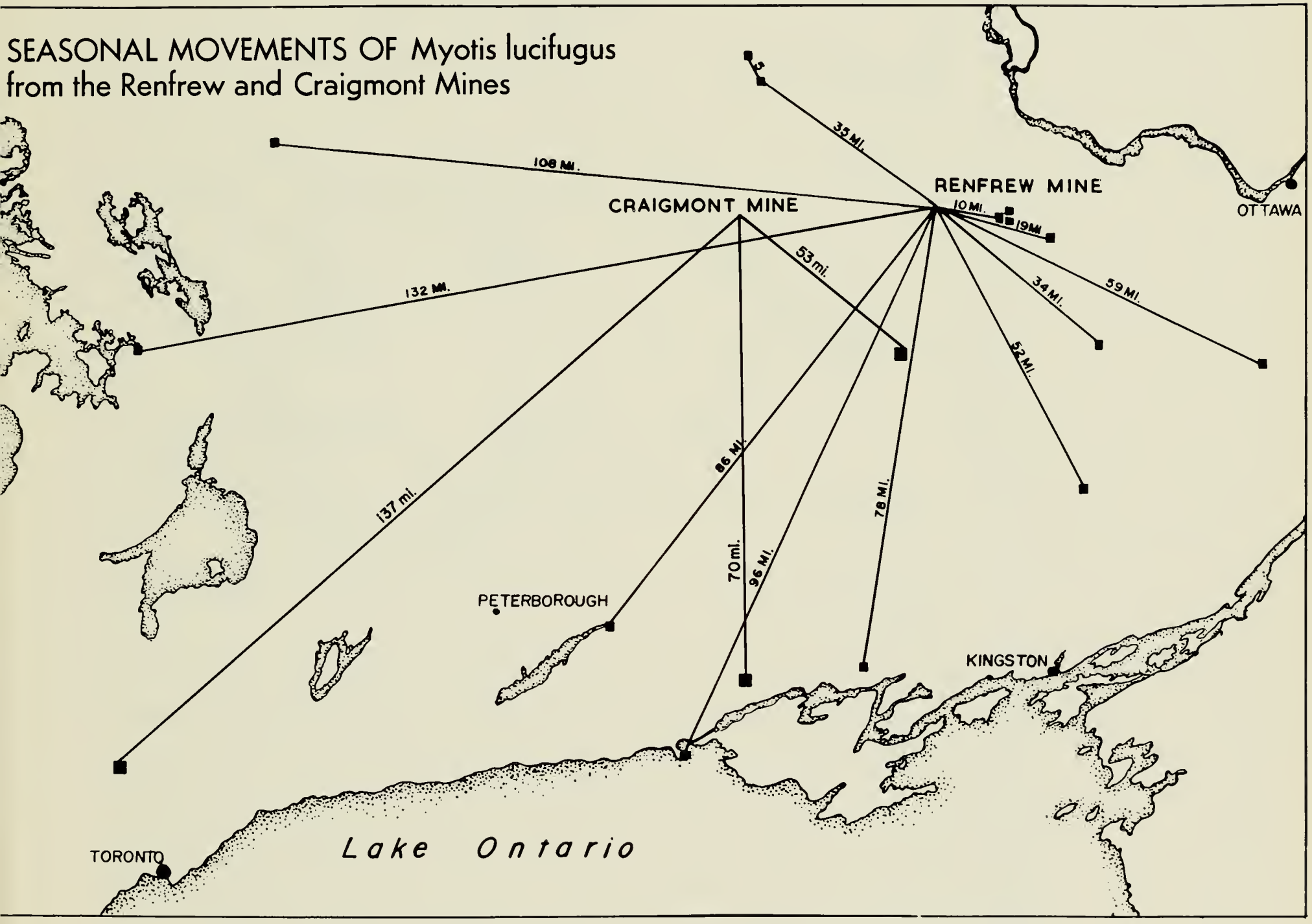

Fig. 4-Seasonal movements of Myotis lucifugus from the Renfrew and Craigmont mines.

usually in directions other than north. The greatest distances were to the west, whereas the shorter more numerous displacements were to the east. The greatest distance flown was 137 miles, from the Craigmont mine to King City (York County). Four recoveries were made from the Craigmont mine, one 53 miles to the south-southeast, one 70 miles south and one 137 miles southwest (Fig. 4). Movements from Tyendinaga and Moira caves were all to the south and west, except for five short ( 7 and 11 miles) recoveries to the northwest (Fig. 5). Most of the recoveries from these caves were made at a colony in Presqu'île Provincial Park. The one recovery of a bat banded at Tyendinaga by Hitchcock (1965) was made east of 


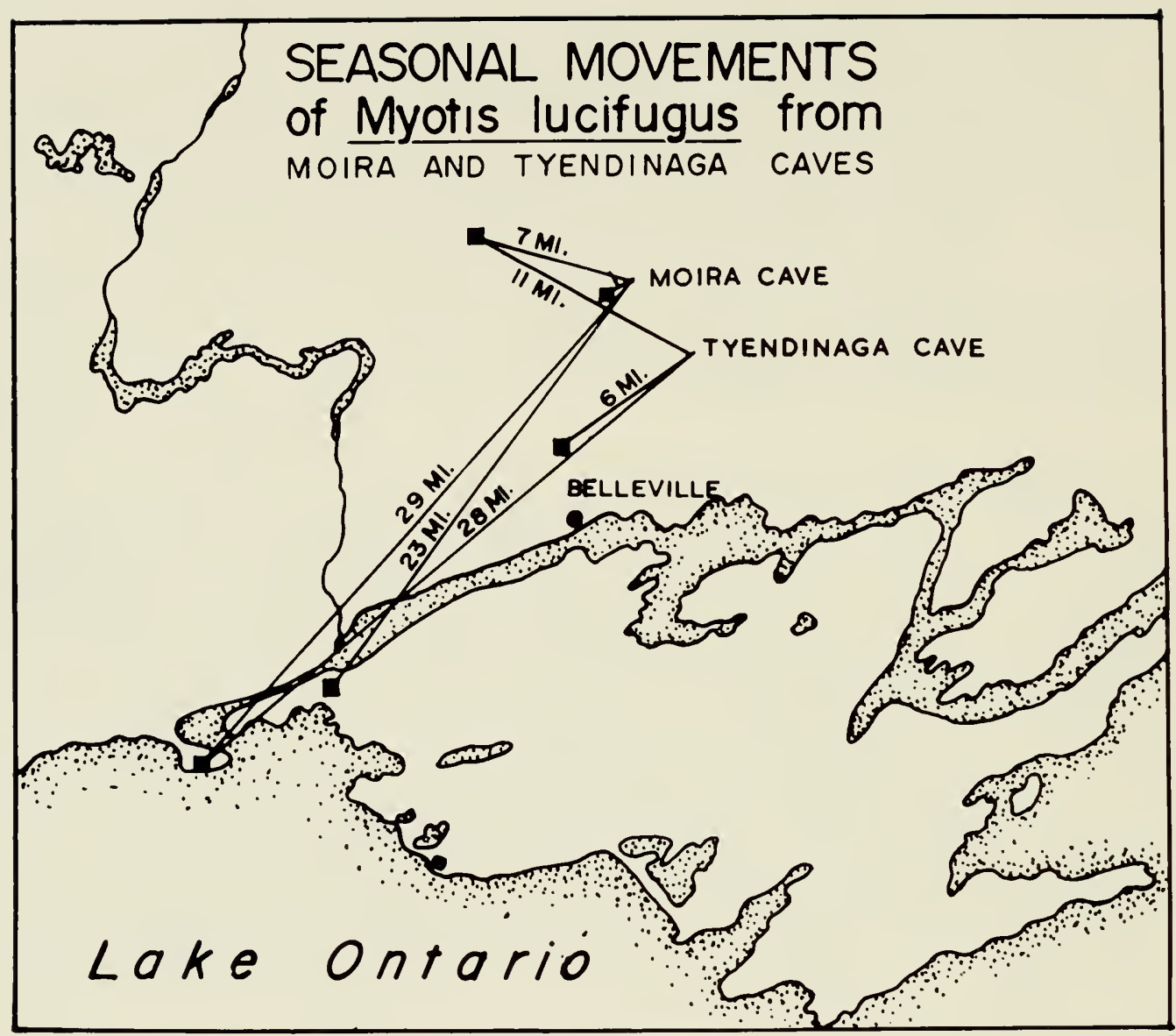

Fig. 5-Seasonal movements of Myotis lucifugus from Moira and Tyendinaga caves.

Presqu'île at Consecon; one bat from Moira cave was recovered there (23 miles SW) during this study.

I recovered two bats banded by Hitchcock at Paradox Iron mine in New York State 160 miles to the east-southeast, one at Lyndhurst and one at Sydenham, two villages north of Kingston. Davis and Hitchcock (1965) reported one recovery from Paradox mine at Alexandria Bay which is located between the mine and the recovery locations for this study.

Some $M$. lucifugus in the Kingston area moved to the east-southeast to hibernate. Bats hibernating at the Renfrew mine arrived from the west, east and south, but rarely from the north. The Craigmont mine attracted bats from the south and west, but in some cases from the same areas where recoveries had been made of bats banded at the Renfrew mine. Many bats from Tyendinaga and Moira caves and Craigmont mine spent the summer in the vicinity of Presqu'île Provincial Park, indicating further overlap of summer ranges.

Hitchcock (1949), Twente (1955a) and Phillips (1966) have reported that bats moved short distances after arousal from hibernation, and Griffin (1940, 1945) observed movement from one hibernaculum to another. There was a tendency for bats to return to that section of the Renfrew mine where they had been hibernating before disturbance (Fig. 6), but they did 


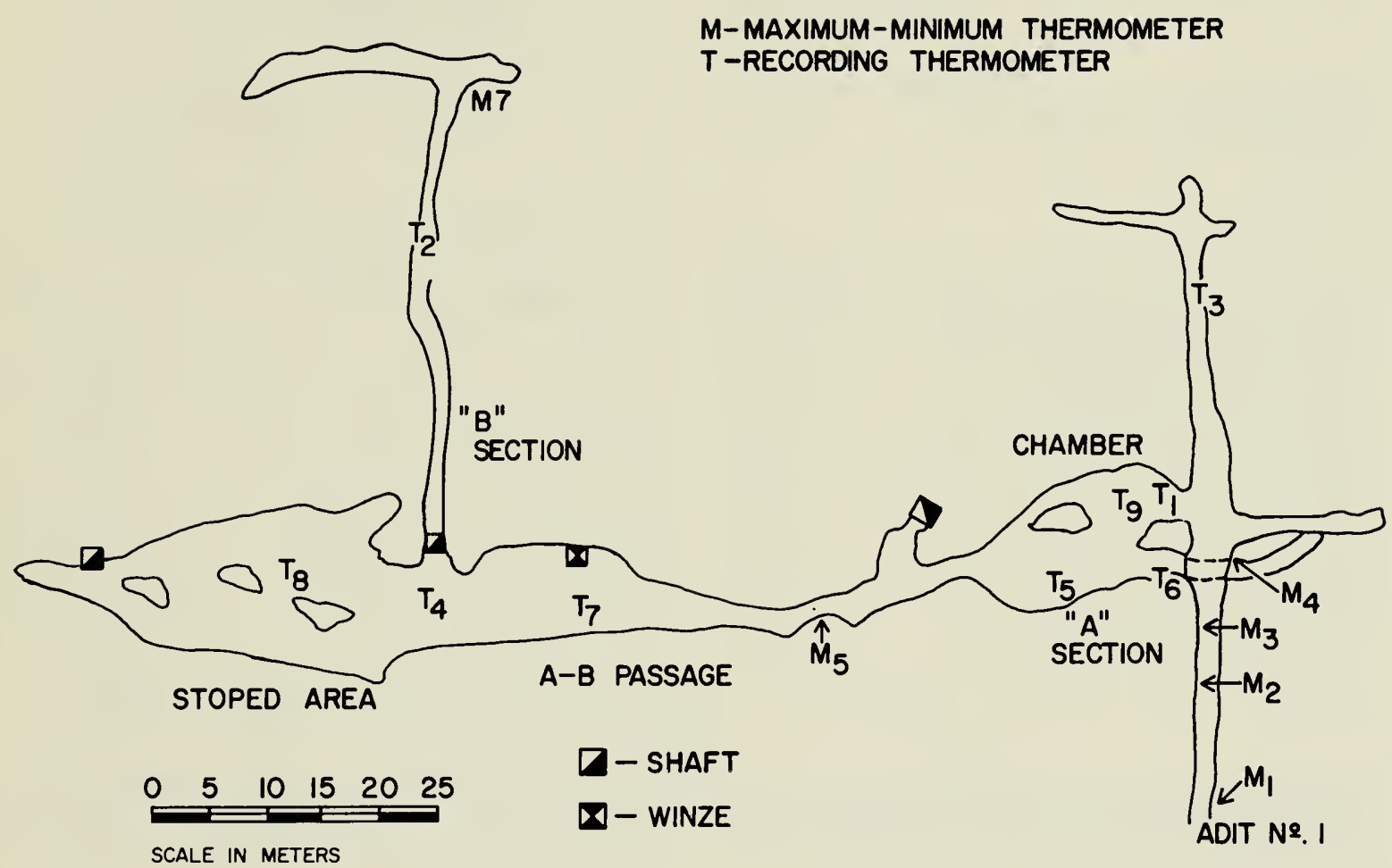

Fig. 6-Outline of the Renfrew mine showing the location of recovery sites and the distribution of thermometers.

not usually return to the precise site from which they had been taken. Of 500 bats recovered during the winters of 1966-67 and 1967-68 at the Renfrew mine, $77 \%$ were subsequently recaptured in that part of the mine (section $\mathrm{A}$ or $\mathrm{B}$ ) where they had been originally banded; $4 \%$ had moved from section $\mathrm{A}$ to section $\mathrm{B}$ and $15 \%$ the other way; $4 \%$ were recovered in both sections subsequent to banding. This tendency of $M$. lucifugus hibernating in sections $\mathrm{A}$ and $\mathrm{B}$ of the Renfrew mine is probably related to the history of the mine prior to 1965 when an adit was blasted through on the third level (Fig. 7) which allowed drainage of the second level. This established a dry connection between sections A and B on the first level and allowed mixing of the populations in the two sections.

In this study, four male $M$. lucifugus changed hibernacula. Two of these were banded on 5 October 1966 at Moira cave and were subsequently recovered some 75 miles away at the Renfrew mine on 3 December 1966 and 23 April 1968. The third, recorded at Tyendinaga cave on 20 March 1966, was later recovered in the Renfrew mine on 23 March 1968 (75 miles away). The fourth, banded at the Bryson mine on 3 November 1967, was later recovered about 28 miles away at the Renfrew mine on 23 March 1968. Thus, two of these bats had moved between two hibernacula in one winter.

Cockrum (1956) suggests that local movements of bats from one roost to another occur during the summer and are often the result of disturbance. 


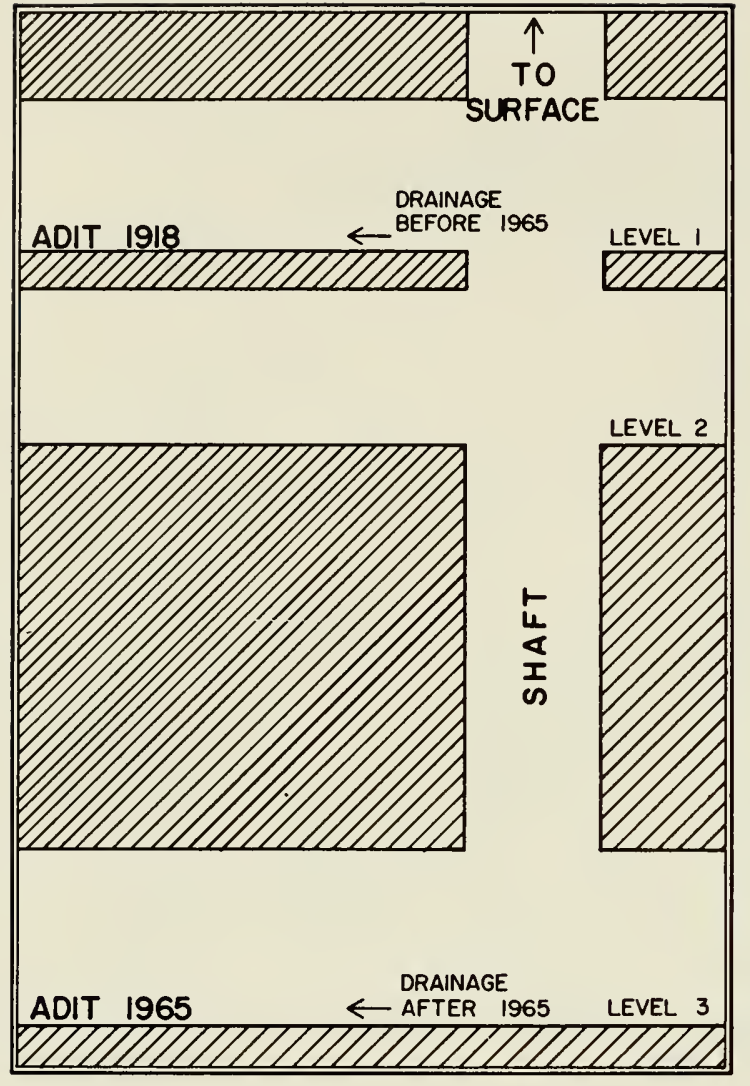

SCALE IN METERS

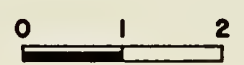

Fig. 7-Diagrammatic cross-section of the Renfrew mine to show the relationship between levels and the change in drainage after an adit was opened in 1965.
I recorded several movements between neighbouring nursery colonies. Three active nursery colonies were discovered within a quarter mile radius of Chaffey's Locks during the summer of 1964. Twelve adult females moved between these colonies, one being caught in all three. In 1965 , after one of the colonies was sealed, at least 54 bats changed roosts, 24 moving from the closed colony to the other two. In 1966 and 1967 I set mist nets in other areas around Chaffey's Locks and found bats originally banded in 1964 still in the general area but not in any of the known colonies. I observed further inter-colony movement at Algonquin park when 50 adult females were banded at Tanamakoon Camp on 18 June 1968 and two were captured the next day at the Algonquin Park Museum, one mile away.

It is not known how much of the movement between nursery colonies is the result of disturbance, but as the bats were undoubtedly familiar

with the locations of alternate summer and winter roosts, such movements may occur naturally. Wimsatt (1969) reports that Desmodus rotundus also move between roosts.

\section{ENVIRONMENT OF ROOSTS}

A problem bats face is conservation of energy (Twente, 1955a). In winter they require a hibernation site warm enough to prevent them from freezing, but cool enough to ensure survival based on accumulated fat. The ambient temperatures of hibernacula determine the metabolic rate of the torpid bat and so have a direct effect upon the geographical limits of different species, e.g. Rhinolophus blasii do not occur in caves where the temperature is less than $14^{\circ} \mathrm{C}$ (Dulic, 1959).

Ecologists who study bats agree that different species usually occupy different sites within hibernacula. Twente (1955a) compared the roosts selected by four species in southern Kansas and Oklahoma (Myotis velifer, Eptesicus fuscus, Plecotus townsendii and Antrozous pallidus). The following workers have provided comparative data for vespertilionids in southcentral United States (Hall, 1962-Myotis sodalis), northwestern Texas 


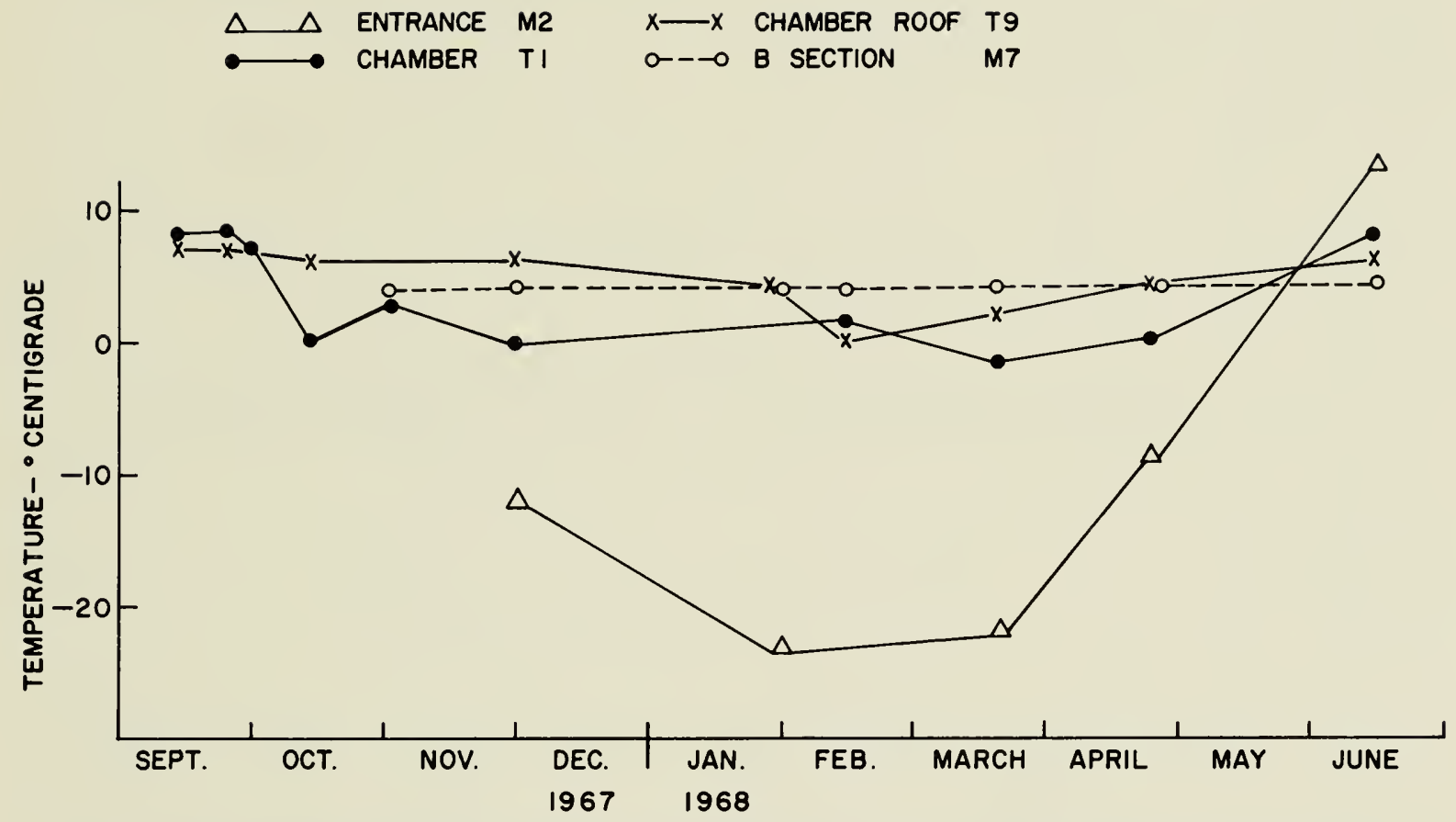

Fig. 8-Temperatures in areas of the Renfrew mine with the largest concentrations of bats.

(Tinkle and Patterson, 1965-M. velifer) and Kansas (Phillips, 1966Eptesicus fuscus).

I placed thermometers at different locations in the Renfrew mine (Fig. 6) to obtain data about the temperatures of roosts selected for hibernation by $M$. lucifugus. Temperatures from areas with the largest concentrations of hibernating $M$. lucifugus are compared with mine entrance temperatures in Figure 8. Temperatures from unoccupied areas are shown in Figure 9. No differences in temperatures between hibernating bats, the rocks they were clinging to and the air around them was observed with mercury thermometers or thermistors.

In Ontario $M$. lucifugus hibernates in those parts of caves or mines where the temperature does not go below freezing. Clusters of bats were observed in peripheral areas of hibernacula in the fall and late spring. They moved into the deeper recesses only when the temperatures at the peripheral sites fell below freezing.

$M$. lucifugus hibernates in areas where the humidity (hair hygrometer) ranges from 70 to $95 \%$. In September 1969 additional humidity readings, obtained with an electrolytic AMLAB Porto-hygrometer, indicated that Ontario mines and caves used by $M$. lucifugus as hibernacula have humidities consistently higher than $90 \%$. Areas in caves where the temperatures fell below freezing have lower relative humidities and greater air movement.

Four bats that shared hibernacula with $M$. lucifugus were $M$. keenii, M. subulatus, Pipistrellus subflavus and Eptesicus fuscus. Although $M$. keenii and $P$. subflavus occupied similar sites (temperature and humidity) for hibernation, they were rarely found in physical contact with $\mathrm{M}$. luci- 


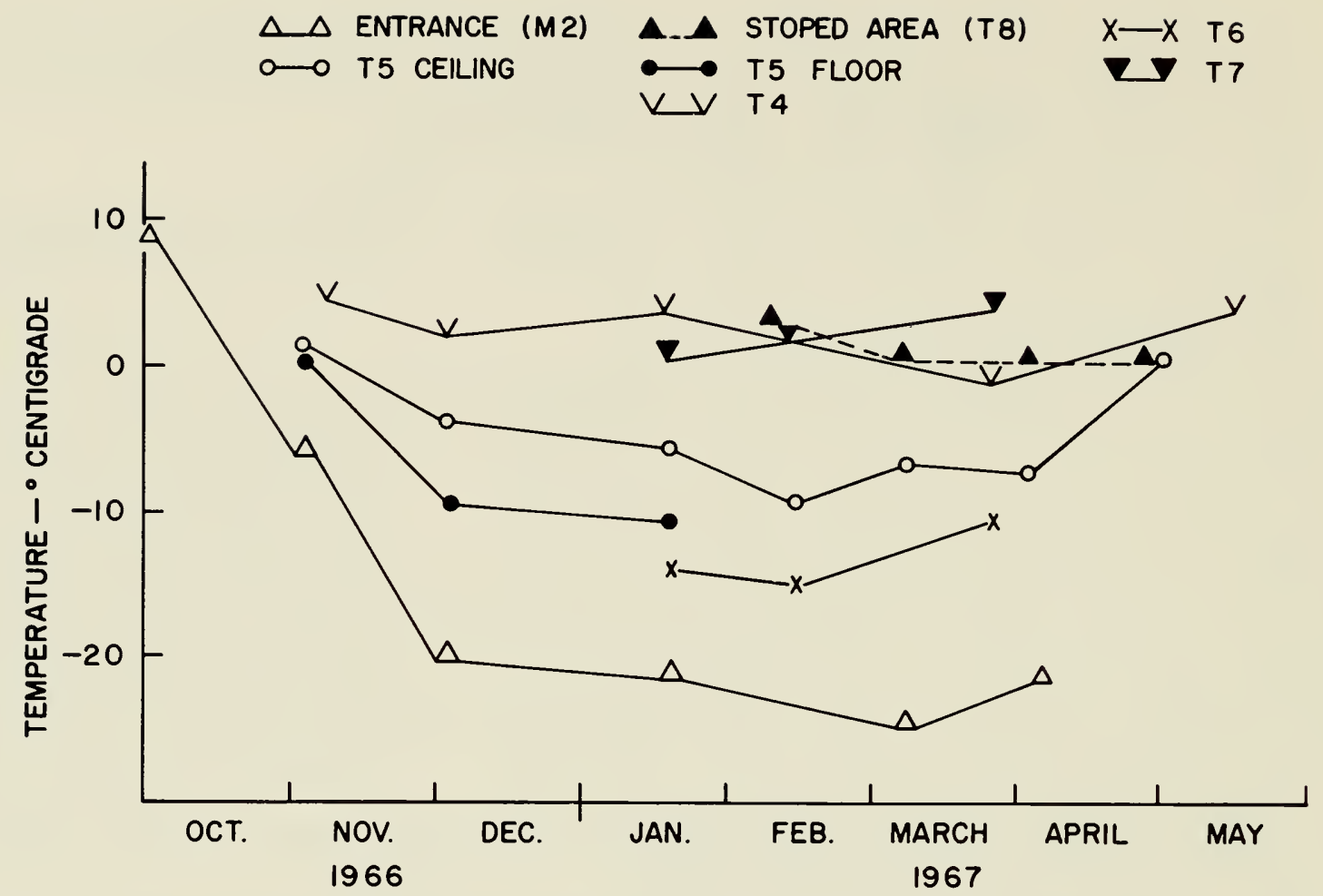

Fig. 9-Temperatures in other parts of the Renfrew mine.

fugus. In some northern Ontario hibernacula, however, small clusters of less than five hibernating bats included $M$. lucifugus and M. keenii. Myotis subulatus and Eptesicus fuscus hibernated together in cooler drier areas where subfreezing temperatures occurred. M. subulatus, however, never hibernated in contact with $M$. lucifugus, but $E$. fuscus did on rare occasions. A fourth species of Myotis, $M$. sodalis is not recorded from Ontario but was observed with $M$. lucifugus at Watertown, New York (Fenton, 1966b). There $M$. lucifugus hibernated in wetter parts of the caves, as had been observed by Hall (1962).

$M$. lucifugus was found to occupy two different types of summer roosts during this study. One, referred to as nursery colonies, comprised up to 1,000 adult females and young and was used by females for parturition and rearing young. The second type of roost, referred to as shelters, was occupied by males and occasionally by presumably non-parous females. Shelters harboured from one to 20 bats.

Nursery colonies and shelters of $M$. lucifugus were usually situated in buildings. Nursery colonies were established in the attics of buildings adjoining lakes and forested regions; in contrast, E. fuscus selected buildings surrounded by open fields. I did not see nursery colonies of mixed species composition. The attics of buildings used as nursery colonies by $M$. lucifugus were invariably dark whereas nursery colonies of $E$. fuscus occurred in more illuminated attics. Female $M$. lucifugus also established nursery colonies between adjoining sections of buildings and in the spaces between roofing and the boards of the roof.

Shelters of $M$. lucifugus were located behind window shutters, in the spaces of rolled-up awnings, beneath layers of tar paper and behind the 


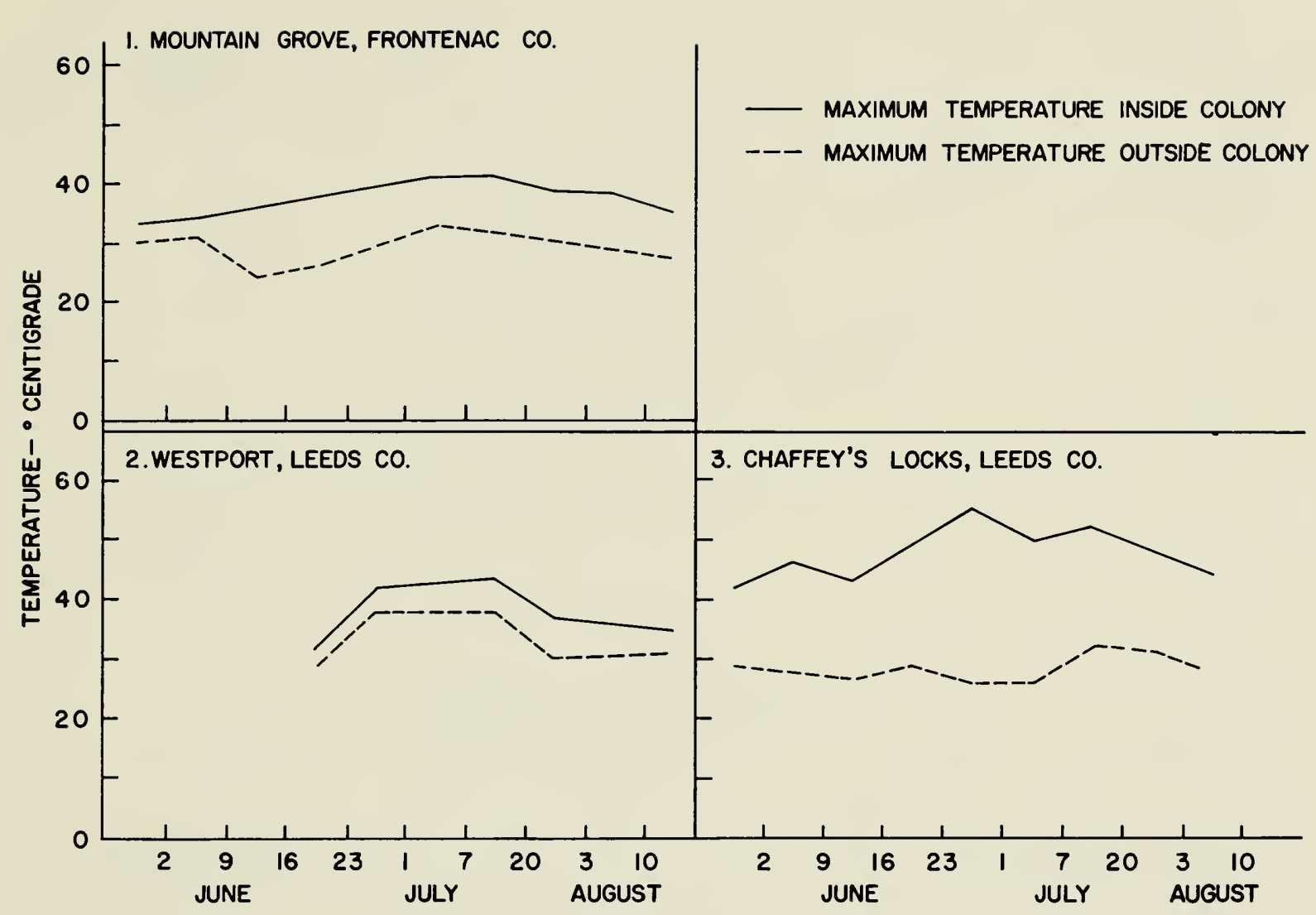

Fig. 10-Temperatures from nursery colonies of Myotis lucifugus in Ontario.

metal flashing around chimneys and eaves. This species also takes refuge under flat rocks (Mr. R. V. Lindsay, pers. comm.).

Temperatures were obtained for both nursery colonies and shelters utilized by $M$. lucifugus. When maximum temperatures inside nursery colonies are compared with those outside (Fig. 10), it is obvious that those inside the colonies are consistently higher than those outside (highest inside was $55^{\circ} \mathrm{C}$, cf. $38^{\circ} \mathrm{C}$, the highest outside). Inside minima were also consistently higher than outside minima. Differences between inside and outside were accentuated on sunny days. Relative humidities inside and outside the nursery colonies were the same.

The high temperatures of nursery colonies may foster lactation and growth of the young, but precise data on these points are lacking. Henshaw and Folk (1966) found that juvenile $M$. lucifugus were more temperature tolerant than adults. Davis (1967) suggested that the great range of temperature tolerance of this species fostered its northerly distribution by allowing the rearing of young under conditions conducive to rapid growth.

Temperatures outside the window shutters at the Queen's University Biology Station were consistently higher than those in the spaces behind the shutters (Fig. 11). Temperatures behind shutters used as shelters by $M$. lucifugus were higher than those behind unoccupied shutters. These bats selected the warmest unexposed sites as shelters. Frequently, bats found behind closed shutters and in other summer shelters were torpid, but those in nursery colonies were not. Herreid (1963a) found that $M$. lucifugus has a higher survival rate in torpor than at $27^{\circ} \mathrm{C}$. Menaker (1962) 


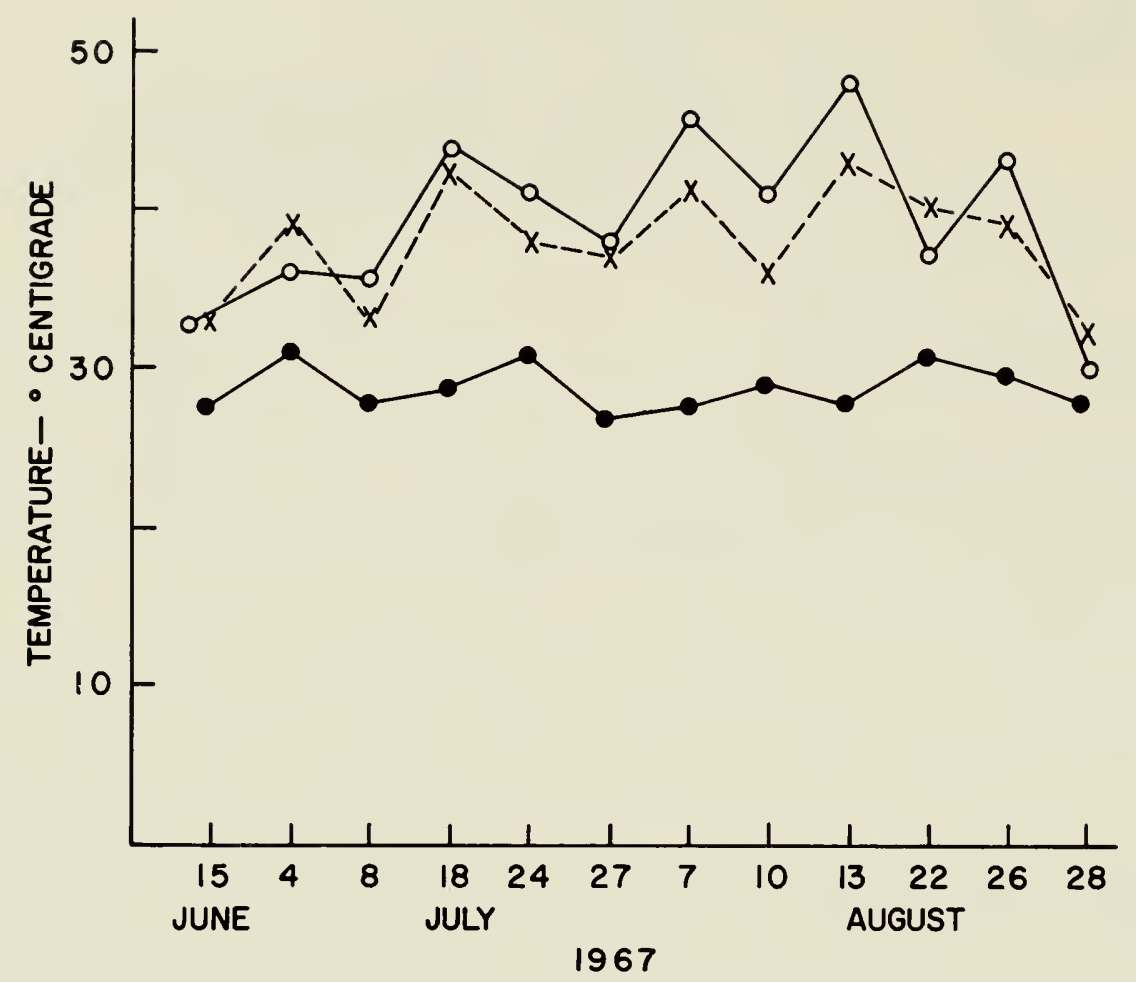

$\multimap$ OUTSIDE SHUTTER

$X--X$ OCCUPIED SHUTTER

$\longrightarrow$ UNOCCUPIED SHUTTER

Fig. 11-Temperatures from window shutter areas at the Queen's University Biological Station near Chaffey's Locks, Ontario.

reported that in summer $M$. lucifugus required external heat to effect arousal from torpor.

Females and young in nursery colonies frequently formed clusters at the peaks of the roofs and on chimneys. These clusters were often dense and consisted of two or three layers of bats. All of the bats in the clusters were alert and usually emitting audible squeaks. Licht and Leitner (1967) found that Myotis californicus formed clusters at $32^{\circ} \mathrm{C}$, but were more dispersed and usually not in physical contact with one another at $40^{\circ} \mathrm{C}$.

In nursery colonies females and young may have clustered together to maintain high body temperatures on overcast days when the colony temperature was low, whereas in shelters the bats did not cluster and were frequently torpid. Stones and Wiebers (1967) found that in summer, male $M$. lucifugus would not enter torpor until the ambient temperature fell below $27^{\circ} \mathrm{C}$.

Chew and White (1960), Herreid and Schmidt-Nielson (1966) and Licht and Leitner (1967) have discussed pulmocutaneous water loss by bats in dehydrating conditions. Studier et al. (1970) showed that diurnal water loss by $M$. lucifugus in nursery colonies was the same for single bats as for groups of four, suggesting that small clusters may not aid the bats in preventing dehydration.

\section{POPULATION STUDIES}

Unequal sex ratios are well known in both summer and winter colonies of bats (Mohr, 1932, 1945; Beer, 1955; Davis 1959; Davis and Hitchcock, 1964, 1965; Hitchcock, 1949, 1950, 1965). In the summer before parturition, nursery colonies of $M$. lucifugus are composed almost entirely of 
adult females; males predominate in hibernating populations. The sex ratio for newborn $M$. lucifugus in southeastern Ontario was nearly 1:1 (45\% of 203 juveniles collected during this study were males).

Sex ratios of hibernating $M$. lucifugus were obtained from random samples of 50 or more bats and are compared with those of Hitchcock (1965) and Davis and Hitchcock (1965) in Table V. Sites are listed from north to south, and sample size and the month are given. Continuous data were obtained from the Renfrew mine where the lowest percentage of males was 43 in October and the greatest 99 in May. The lowest percentages of hibernating males were observed at Gowganda mine in northern Ontario $(63 \%)$ and at Moira cave in southern Ontario (65\%). At all other hibernacula males represented at least $73 \%$ and as much as $91 \%$ of the torpid population.

\section{TABLE V}

Percentage of male Myotis lucifugus at hibernacula in the study area

\begin{tabular}{|c|c|c|c|c|c|c|c|c|c|}
\hline \multirow{2}{*}{$\begin{array}{c}\text { Hiber- } \\
\text { naculum }\end{array}$} & \multicolumn{8}{|c|}{ Percentage of males (sample size in brackets) } & \multirow[b]{2}{*}{ Mean } \\
\hline & Sept. & Oct. & Nov. & Dec. & Jan. & Feb. & March & May & \\
\hline $\begin{array}{c}\text { Jackfish } \\
\text { mine }\end{array}$ & $\begin{array}{l}84 \\
(232)\end{array}$ & $\begin{array}{l}83 \\
(591)\end{array}$ & - & - & $\begin{array}{l}82 \\
(210)\end{array}$ & - & - & - & 83 \\
\hline $\begin{array}{l}\text { Schreiber } \\
\text { mine }\end{array}$ & - & $\begin{array}{l}75 \\
(545)\end{array}$ & - & - & $\begin{array}{l}83 \\
(196)\end{array}$ & - & - & - & 79 \\
\hline $\begin{array}{l}\text { Gowganda } \\
\text { mine }\end{array}$ & - & $\begin{array}{l}63 \\
(273)\end{array}$ & - & - & - & - & - & - & 63 \\
\hline $\begin{array}{l}\text { Desbarats } \\
\text { cave }\end{array}$ & - & $\begin{array}{l}83 \\
(257)\end{array}$ & - & - & - & - & - & - & 83 \\
\hline $\begin{array}{l}\text { Webbwood } \\
\text { mine }\end{array}$ & $1-$ & $\begin{array}{l}83 \\
(644)\end{array}$ & - & - & $\begin{array}{l}89 \\
(142)\end{array}$ & - & - & - & 86 \\
\hline $\begin{array}{r}\text { Bryson } \\
\text { mine }\end{array}$ & - & $\begin{array}{l}73 \\
(147)\end{array}$ & - & - & - & - & - & - & 73 \\
\hline $\begin{array}{l}\text { Craigmont } \\
\text { mine }\end{array}$ & - & - & $\begin{array}{l}84 \\
(393)\end{array}$ & - & - & - & - & - & 84 \\
\hline $\begin{array}{l}\text { Renfrew } \\
\text { mine }\end{array}$ & $\begin{array}{l}43 \\
(259)\end{array}$ & $\begin{array}{l}86 \\
(480)\end{array}$ & $\begin{array}{l}77 \\
(772)\end{array}$ & $\begin{array}{l}82 \\
(828)\end{array}$ & $\begin{array}{l}83 \\
(761)\end{array}$ & $\begin{array}{l}86 \\
(553)\end{array}$ & $\begin{array}{l}86 \\
(785)\end{array}$ & $\begin{array}{l}99 \\
(156)\end{array}$ & 78 \\
\hline $\begin{array}{l}\text { Moira } \\
\text { cave }\end{array}$ & - & - & - & $\begin{array}{l}67 \\
(216)\end{array}$ & $\begin{array}{l}65 \\
(67)\end{array}$ & - & $\begin{array}{l}80 \\
(57)\end{array}$ & - & 70 \\
\hline $\begin{array}{l}\text { Moira } \\
\text { cave }\end{array}$ & - & - & - & - & $\begin{array}{l}69 \\
(132)\end{array}$ & - & - & - & - \\
\hline \multirow[t]{2}{*}{$\begin{array}{l}\text { Limerick } \\
\text { cave }\end{array}$} & - & - & - & - & - & - & $\begin{array}{l}91 \\
(81)\end{array}$ & - & 91 \\
\hline & \multicolumn{8}{|c|}{ Mean percentage of males from the study area } & 79 \\
\hline \multirow{2}{*}{\multicolumn{9}{|c|}{$\begin{array}{l}\text { Wakefield cave, Quebec } 1 \\
\text { Tyendinaga cave Ontario } 1\end{array}$}} & 75 \\
\hline & & & & & & & & & 77 \\
\hline \multicolumn{9}{|c|}{ Aeolus cave, Vermont ${ }^{2}$} & 58 \\
\hline
\end{tabular}

1Hitchcock (1965)

2Davis and Hitchcock (1965) 
Clusters of hibernating bats were either loosely or tightly packed (Fig. 12). Males were significantly more common than females in the larger clusters (Fig. 13; $0.01<\mathrm{p}<0.05$ ). Females hibernated alone or in small clusters as was noted by Davis and Hitchcock (1964), but even in the small clusters the proportion of males usually exceeded 0.5 (0.33 to 0.74 ; Table VI).

Hitchcock (1965) suggested that the different environmental conditions of the roosts occupied by male and female $M$. lucifugus during the summer could account for the apparent differential survival of the sexes, i.e. in the hot and crowded nursery colonies adult females were subject to higher rates of infestation by parasites. The number of bats with ectoparasites, including ear and wing mites and fleas, was counted in August 1968. Of $967 M$. lucifugus examined, $14 \%$ were infected with ear mites, $7 \%$ with wing mites and $7 \%$ with fleas. More males than females were infested with ear mites (18\% vs. $9 \%$ ), but for wing mites and fleas the incidences of infestation were almost equal. Adult and juvenile $M$. lucifugus showed the same rate of infestation by all three groups of ectoparasites. These data do not support Hitchcock's (1965) idea concerning the effect of roost environment on survival.

Availability of roosts limits the distribution of $M$. lucifugus in Ontario. This has been suggested for $M$. keenii in eastern Canada by Peterson (1966) and for Plecotus (= Corynorhinus) rafinesquii in California (Pearson et al., 1952). Twente (1955b) suggested that predation was a limiting factor for bat populations with low reproductive rates. Manville (1963) has pointed out the importance of accidental mortality in bats.

Twente (1955b) found that snakes, hawks, owls and raccoons (Procyon lotor) were preying on bats in Kansas and Oklahoma. Few predators seem to feed habitually on bats in Ontario. Stomach contents of hawks and owls included no bat remains (Snyder, 1947). Downing and Baldwin (1961) reported a Sharp-shinned Hawk (Accipiter striatus) catching a Lasiurus borealis at Point Pelee, Ontario and Mr. B. K. McKay (pers. comm.) found bat remains in the stomach of a juvenile Red-tailed Hawk (Buteo jamaicensis) captured near Pickering, Ontario. Mr. D. H. Johnston (pers. comm.) observed a marten (Martes americana) feeding on $M$. lucifugus in a nursery colony in Algonquin Park. Hitchcock (1965) reported a Peromyscus leucopus in the Craigmont mine near the carcasses of four bats and assumed that the mouse was the predator.

I first noticed predation on hibernating bats in Stone House cave on 22 February 1964, when a dead Eptesicus fuscus was found on the floor of the cave. The bat had been skinned by an unknown predator, and the skin and wings discarded intact. I saw no tracks or droppings in the vicinity of the remains. Peromyscus maniculatus were frequently observed in summer and winter in the Renfrew mine between 1965 and 1969. The mice nested in the mine and, by ear tagging, I established that six lived in the mine. In summer mice were caught in the mine but foraged outside at night; in winter the absence of tracks at the entrance to the mine suggested that they did not venture outside. 


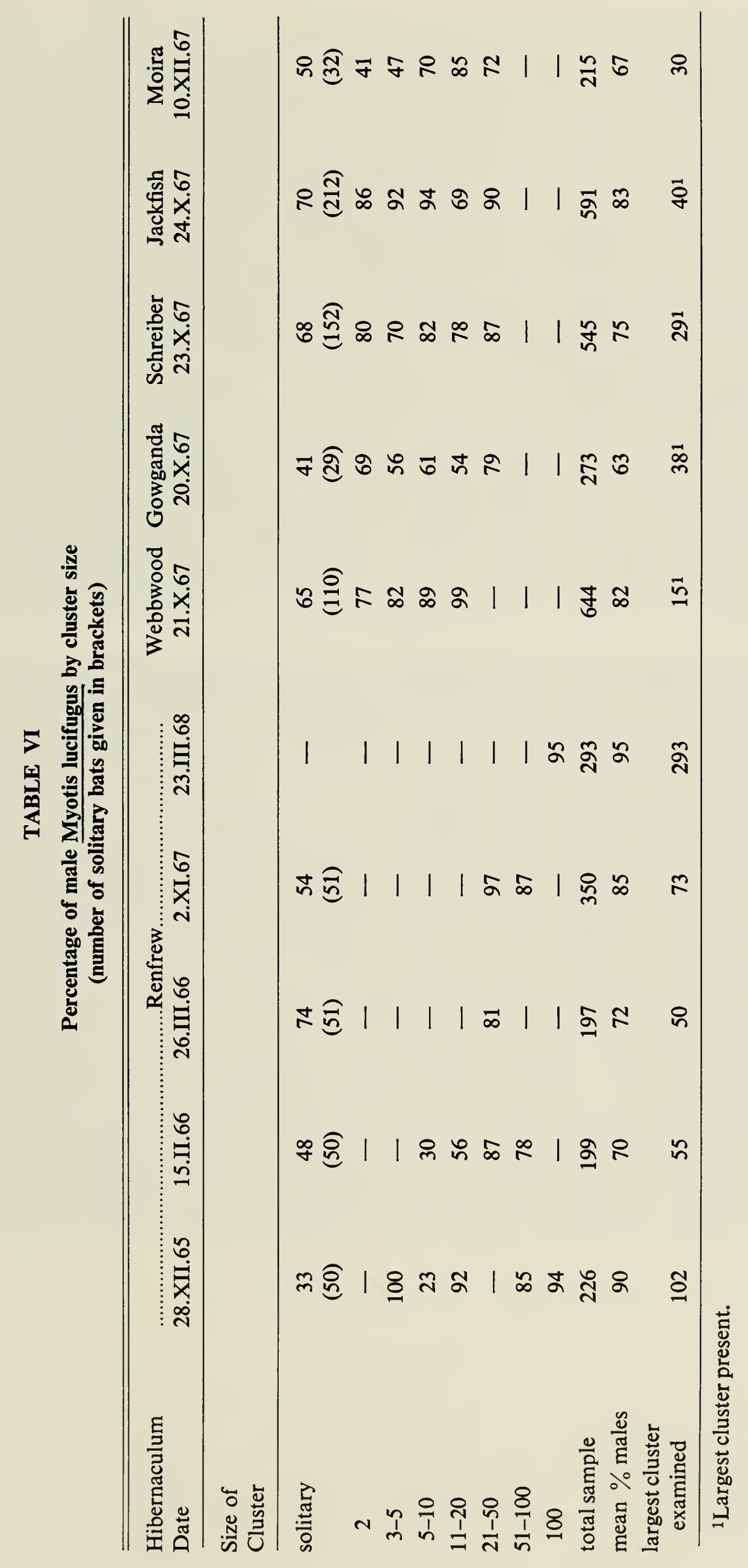



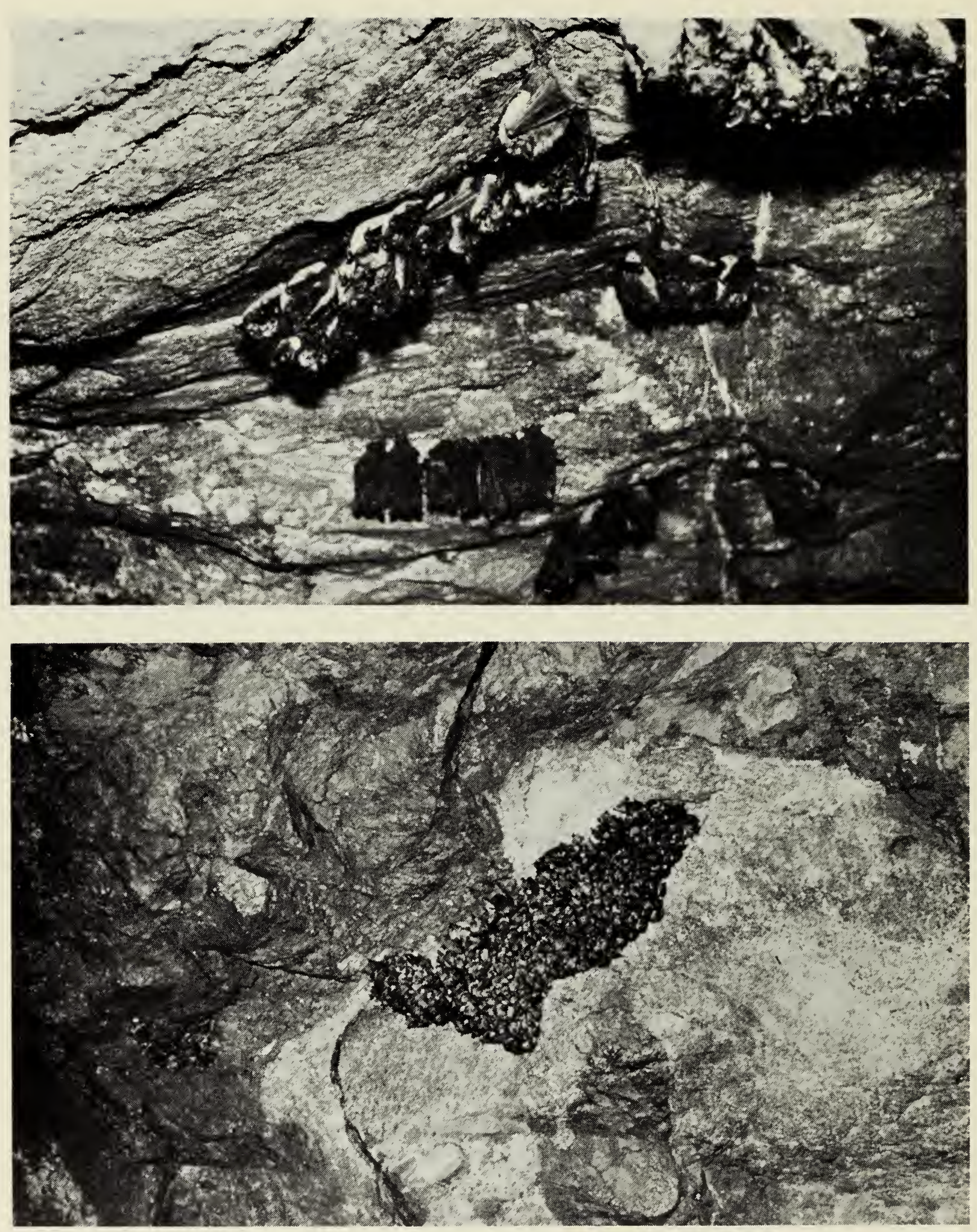

Fig. 12-Clusters of Myotis lucifugus at the Renfrew mine: $a$-loosely packed, and $b$-tightly packed. 


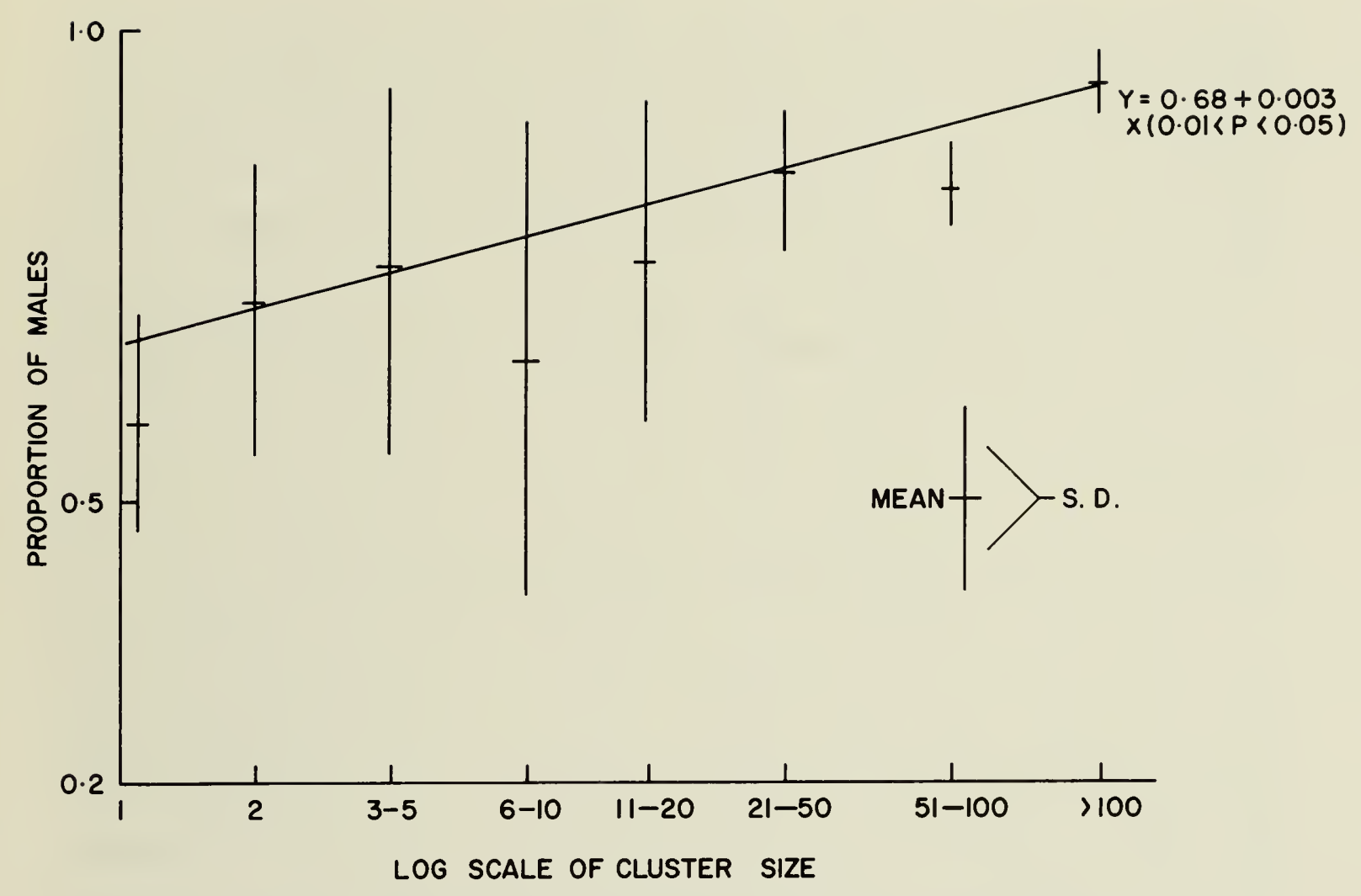

Fig. 13-Proportion of male Myotis lucifugus by cluster size.

Two mice placed in a cage with an injured $M$. lucifugus killed and ate the bat. The mice characteristically left the wings and skin intact and chewed open the back of the skull and ate the brains. The number of bat carcasses of this nature which were found in the Renfrew mine suggests that the mice depended upon bats as a regular source of food. I saw Peromyscus in other hibernacula and predation by these rodents may be common. Mice have been infected with rabies by eating infected tissue (Soave, 1966), and predation by Peromyscus may link bat and carnivore populations in the natural cycle of the transmission of rabies.

Apart from those bats taken by mice, predation is probably not an important limiting factor of bats in Ontario. On the other hand, the activities of man are a major cause of bat mortality. Fumigation of nursery colonies may wipe out hundreds of bats, and in the winter hibernating bats are especially vulnerable to wanton killing by vandals. The ingrained fear of bats contributes to their destruction by man, whether with fumigants or tennis racquets.

Flooding of caves has been a factor responsible for mass mortality of bats (Hall, 1962 and DeBlase et al., 1965). Bats are also inadvertantly killed during mining operations, e.g. at the McIntyre-Porcupine mine in Timmins, large numbers of $M$. lucifugus were killed when they were drawn into the blades of a large fan used to ventilate the mine.

Large concentrations of bats are susceptible to cataclysmic events of the types mentioned above. This may account for the great sensitivity to disturbance shown by $M$. lucifugus. During my first visits to nursery colonies, I saw bats in exposed areas. On subsequent visits they had moved into 
cracks and other inaccessible positions. Further disturbance caused abandonment of the roost. Some movements of $M$. lucifugus between nursery colonies and between hibernacula may be attributed to such disturbance. A familiarity with the locations of alternate roosts would be of definite advantage to the bats, perhaps being the difference between survival and death, especially in the winter.

Pearson et al. (1952) did not consider food to be a serious limiting factor for bat populations and no data were accumulated to suggest otherwise.

\section{Discussion}

TEMPERATURE AND HUMIDITY OF HIBERNACULA

It is evident that temperature is an important factor in the selection of hibernacula by bats. The temperatures from within the deeper recesses of caves and mines where there is little or no air circulation remain fairly constant during the year, the amount of variation being affected by the relative proximity to the entrance. In peripheral regions of hibernacula, low winter temperatures (to $-25^{\circ} \mathrm{C}$ outside the Renfrew mine) render these areas unsuitable for bat hibernation.

Although the relationship between temperature and hibernation is apparently clear, that of humidity is not, and tolerances of different species to different humidities are not the same (Pirlot, 1946). The optimal humidity for $M$. lucifugus, while not substantiated, is seemingly above $85 \%$. Pirlot (op. cit.) showed that torpid bats in areas of low temperatures and low humidity required water for drinking for survival. This suggests that water is lost through respiration (Herreid and Schmidt-Nielson, 1966) and/or evaporation from the body surface. Sisk (1957) found that the sweat glands on the body surface of $M$. lucifugus are not controlled by conditions of evaporation.

Fisher and Manery (1967) suggested that oxidation of fat produced excess water. Presumably part of this water is converted to urine, and the remainder is lost by evaporation. When water loss is excessive, drinking of water would be necessary to compensate.

\section{CLUSTERING OF HIBERNATING BATS}

Aggregations of hibernating bats, ranging from a few isolated individuals to large tightly-packed clusters of over 1,000, were observed during this study. Clustering has been interpreted as having a thermoregulatory function (Twente, 1955a), but the data on temperatures from $M$. lucifugus indicate that clustering does not keep the bats warm. As body heat might be absorbed by rock, clustering was thought to act as a cooling device for $M$. velifer (Twente, 1955a). My data for M. lucifugus do not support this.

Because of decreased exposure of body surface to the environment, bats from clusters lost weight at a slower rate than solitary bats (Table II). Bats at the edge of clusters, however, have more surface area exposed than those at the centre and did not weigh significantly less. Although solitary 
bats with coatings of water droplets may not be as susceptible to water loss by evaporation, they were not consistently heavier than dry, isolated individuals. In northern Ontario hibernacula isolated bats with moisture on their fur had heavier coatings of water droplets than those in southern Ontario hibernacula. Clusters of hibernating $M$. lucifugus were much smaller in the northern hibernacula and it is possible that larger amounts of available moisture in northern hibernacula alleviate the need to reduce water-loss by evaporation and therefore reduce the need for clustering.

$M$. lucifugus hibernates in areas of higher available moisture than those chosen by $M$. sodalis. I occasionally found individual $M$. lucifugus in the centres of large clusters of $M$. sodalis and, although the environment of the area occupied by $M$. sodalis was not normally favourable for hibernation of $M$. lucifugus, the microenvironment of the cluster may have rendered it suitable.

\section{HIBERNATION}

The commencement of copulation and the build-up of a torpid population of bats at hibernacula (= second phase of swarming, Fenton, 1969b), may represent, in part, the transition period of Kayser (1965, p. 255), who stated "... entry into hibernation seems to be, first, an exaggeration of the diurnal rhythm." This transition period allows physiological changes shown by Menaker (1962) and Stones and Wiebers (1967). Arousals of bats, both of a spontaneous nature and resulting from the actions of other bats, were observed during the second phase of swarming. Spontaneous arousals at that time may have been caused by the need to defecate, a stimulus that would be lacking when the digestive tract was empty. Arousals stimulated by other bats were caused by both flight disturbance and attempts to copulate.

The stimuli that caused the build-up of the torpid population have not been clearly defined. Hibernating bats were present at the Renfrew mine before the first frost, usually between 20 and 25 September (Brown et al., 1968) and on 25 September in 1967. A reduction in food supply, as reflected by the number of swarming bats with empty stomachs in September (Fenton, 1969b), may be a factor initiating hibernation. During the latter part of August and throughout September in 1967, an ultraviolet light was placed near the entrance to the Renfrew mine to attract insects. Quantitative data were not obtained, but by the middle of September only a few insects appeared at the light.

The simultaneous build-up of the torpid population and the commencement of copulation in early September (Fenton, 1969b) may both be controlled by photoperiod. Pirlot (1946) suggested that hibernation of bats is under endocrine control and the changing day length (26 minutes between 31 August and 15 September) could effect the glandular changes necessary to induce both hibernation and copulation. Changing photoperiod may provide cues to stimulate glandular changes necessary for hibernation, but actual entry into hibernation may be locally accelerated or delayed by climatic conditions. Such a mechanism is known for mammals; e.g. Rust 
(1962) demonstrated that spring moult in Mustela erminea is induced by photoperiod but can be delayed by temperature conditions.

Most heterothermic mammals spontaneously arouse from hibernation and the interval between arousals is longest in $M$. lucifugus (Menaker, 1964). Spontaneous arousals require considerable expenditure of energy (Fisher and Manery, 1967), and long intervals between such arousals have been suggested as the factor allowing survival of hibernating bats which possess ". . . relatively, only half as much stored fat as other heterotherms" (Fisher and Manery, 1967, p. 277).

At least two factors seem to be involved in spontaneous arousal from hibernation by bats. Some bats will arouse from torpor when the ambient temperature of the hibernaculum falls below freezing (Alder, 1926 and Hock, 1951). Experiments by Reite and Davis (1966) showed that $M$. lucifugus exposed to subfreezing temperatures had an increased rate of metabolism (respiration and heart beat) and attempted to arouse. Under natural conditions, therefore, hibernating $M$. lucifugus should and do vacate areas of hibernacula where the temperature goes below freezing.

Thermal arousal may be used to explain the arousal of bats in areas subject to temperature variation, but it does not explain arousals from areas with little temperature variation. If arousals were stimulated only by temperature changes, bats hibernating in areas with constant temperature would not arouse. This is not the case for the first departures of $M$. lucifugus are in April, before there has been any appreciable change in temperature in the thermally stable areas.

Other causes of arousal have been suggested. Rysgaard (1942) observed chitin in the mouth of a torpid Eptesicus fuscus and felt that hibernating bats were consuming hibernating arthropods and that hunger was a stimulus for arousal. Data on weight given here and by Beer and Richards (1956) show that bats were not feeding, as indicated by a constant loss of weight throughout the winter. Kayser (1961) and Kallen (1964) did not think that bats fed while hibernating. Furthermore, the scarcity of hibernating arthropods in Ontario hibernacula indicates that this source of food is not sufficient to support even a small number of bats. Dr. N. Mrosovsky (pers. comm.) reported that when hibernating ground squirrels were disturbed, the energy lost was compensated for by eating. In contrast, the disturbance of hibernating $M$. lucifugus at the Renfrew mine caused an increase in weight loss which was not compensated for by food consumption.

Pirlot (1946) showed that hibernating bats would arouse to obtain water and previously Guthrie (1933) had suggested that thirst was a cause of arousal. The need for water would be governed by rates of metabolism and loss of water by evaporation. Twente (1955a), however, suggested that thirst was only a secondary factor and that the principle cause for arousal was the need to urinate. Fisher and Manery (1967) proposed that water from metabolism was retained for the production of urine and postulated long intervals between arousals. Related to this, they stated, was a relatively high tolerance to accumulated metabolic end products in the body water. Kallen and Kanthor (1967) found that urine formation was 
slow enough to permit long intervals of hibernation as shown by Menaker (1964). Twente (1955a) cited Johnson (1931) who found that ground squirrels aroused from hibernation always voided immediately after becoming active.

Endogenous rhythms, as shown by Menaker (1961) for M. lucifugus, may also have some effect upon the frequency of arousal of the hibernating bat. From the evidence considered above, it seems possible that one major cause of arousal is the result of some aspect of the water economy of the torpid bat; either the nervous strain of a full bladder and/or the need to replace water lost by pulmocutaneous evaporation. The presence of active bats in a hibernaculum also caused arousal from torpor; this could have been related to the ultrasonic cries of the active bats.

Female $M$. lucifugus usually depart from the hibernacula before the males $(99 \%$ of $156 \mathrm{M}$. lucifugus banded at the Renfrew mine on 22 May 1965 were males). Ovulation may be a stimulus for the departure by females, but the lack of environmental fluctuations in the hibernacula does not provide a cue for endocrine action. Guthrie (1933) found that ovulation would occur in February when female $M$. lucifugus were taken from hibernation and maintained at room temperature, suggesting that ovulation does not stimulate departure from hibernation. The earlier departure of females may relate to their propensity for solitary hibernation.

\section{HETEROTHERMY}

Thermoregulation in Chiroptera was surveyed by Brosset (1961) and reviewed by Stones and Wiebers (1965). Representatives of two or three of the 17 families of bats (after Walker, 1964) enter a state of torpor (the Rhinolophidae, the Vespertilionidae, and perhaps the Molossidae). Rhinolophids and vespertilionids are well represented in the north temperate regions of the world and the molossids are cosmopolitan in the tropics and warmer temperate latitudes. Certainly the ability to hibernate fosters this distribution pattern.

Eisentraut (1934, 1938 and 1960), Kayser (1939, 1940, 1950 and 1957), Hock (1951) and Herreid (1936b) have all stated that bats possess the least efficient thermoregulation known in mammals. Hock (1951) added that no physiological distinction existed between the daily lethargy of bats in summer and torpor in bats in winter; this was shown to be incorrect by Menaker (1962).

Hibernation is a special adaptation that has enabled bats to inhabit the temperate regions of the world and has probably evolved from a homeothermic state (Bourlière, 1952; Hanus, 1959 and Twente and Twente, 1964). Brosset (1961) showed that representatives of certain tropical bat families were unable to enter torpor and mentioned the prolonged rest of some of these families which may represent a transitional condition. Twente and Twente (1964) proposed that bats were derived from tropical ancestors which were unable to enter torpor; the presence of advanced forms in the high latitudes supports this.

The ability of bats to enter torpor allows conservation of energy during 
inclement periods. This is especially clear for $M$. lucifugus in non-nursery colony situations. The selection of diurnal roosts and the behaviour in these roosts tend to further support the ideas of Twente and Twente (1964). Females and young in nursery colonies apparently cluster to maintain high body temperatures, which in turn allows them to feed and thus maintain lactation and growth. Males, however, apparently do not cluster during the summer and will enter torpor if not warmed by the environment.

These observations suggest that chiropteran hibernation is a complex phenomenon involving both physiological and behavioural adaptations. The ability of certain bats to enter torpor appears to be a specialized condition rather than being the result of "poor thermoregulation" ( $c f$. Bourlière, 1952; Hanus, 1959 and Twente and Twente, 1964).

\section{THE EFFECT OF MAN}

The extensive use of buildings for nursery colonies and shelters by $M$. lucifugus poses a question as yet not satisfactorily answered: Where were nursery colonies located before the existence of man-made structures? A logical site might be hollow trees. Despite extensive searching, however, I have not located such colonies and to my knowledge none has been reported in the literature. Mumford and Cope (1964) found a nursery colony of Myotis keenii under the bark of a dead elm tree and Christian (1956) found Eptesicus fuscus with young in trees. It is possible that the environment of the structures now used as nursery colonies by $M$. lucifugus allows more efficient rearing of the young than did that of hollow trees or spaces under bark. Bats quickly take advantage of new roosting sites (Brosset, 1966), and a switch to buildings as places to establish nursery colonies would not be unexpected. Moreover, this move may have been accelerated by the extensive logging operations which took place in Ontario during the 19th century. Dr. R. E. Beschel (pers. comm.) suggested that hollow trees would have been more abundant in the virgin forest than they are today. Logging operations, therefore, may have drastically reduced the number of suitable trees for nursery colonies.

If the environment of the artificial roosts is more conducive to efficient rearing of the young, the advent of European man in North America may well have increased the population of $M$. lucifugus. Should this be the case, one would expect to find more bats in rural than in undeveloped areas. With an ultrasonic sound detector (Watson, 1965), it was possible to measure roughly the amount of bat activity over different habitats. Counts were made of the number of times bats flew past the microphone of the ultrasonic detector from dark until dawn at seven locations, for 14 nights, during the summers of 1967 and 1968. Results of these studies (see Fenton, 1969c) indicated that there was more activity over rural areas (Chaffey's Locks on the Rideau Canal) than over undeveloped areas (Winnifred Lake in Algonquin Park).

The greatest concentrations of hibernating bats in the study were found in mines. The largest cave population of $M$. lucifugus (500) in northern Ontario was in Desbarats cave near Sault Ste Marie. Moira cave 
harboured about 200 hibernating $M$. lucifugus, the largest known cave population in southern Ontario. Craigmont and Renfrew mines each harboured over 10,000 hibernating bats annually, and populations of at least $1,000 \mathrm{M}$. lucifugus were known to winter in at least three other mines.

The presence of buildings in Ontario predates the mines by at least 100 years. The Jackfish mine, closed about 1898 , is the oldest now known to be used by bats. The Craigmont and Renfrew mines were shut down in 1918 and other abandoned mines known to harbour bats were closed between 1920 and 1955. There is no evidence that bats have abandoned caves in favour of mines as places to hibernate.

Before the presence of suitable hibernacula, part of the $M$. lucifugus population may have been forced to migrate to more southerly hibernacula, possibly in the eastern United States, including the Schoharie region of New York State, the nearest area with extensive karst development. At least a few bats were occupying the small and sparsely distributed caves in Ontario before mines were present (Churcher and Fenton, 1968).

As so many bats remain unaccounted for, an emigration to areas as yet unknown is possible. To date there are no band recoveries to support this suggestion, but the higher incidence of females in more southerly hibernating populations (Hall and Brenner, 1968 and J. B. Cope, pers. comm.) suggests that some bats, especially females, move south. I have previously suggested that swarming behaviour may serve an important function in the location of suitable hibernacula and as a prelude to migration (Fenton, $1969 \mathrm{~b}$ ). Hibernating populations of $M$. lucifugus in the northern parts of the range are predominantly male, whereas in the central portions of the range females are more common.

Data on movements, including seasonal ones and those between summer or winter roosts, and the observations from swarming, suggest that bats may be familiar with a large area. But the rapidity with which $M$. lucifugus have been shown to exploit new sites remains unexplained. Bats must locate and evaluate potential hibernacula and nursery colonies. That they are capable of doing this is shown by the establishment and increase of a hibernating population of nearly 1,000 in the Bryson mine in less than 10 years. Communication between bats (Twente, 1955b; Möhres, 1967, and Fenton, $1969 \mathrm{~b})$ may be a major factor in the rapid growth of populations at new locations.

\section{Acknowledgments}

The help and advice of Dr. R. L. Peterson during all phases of the study are gratefully acknowledged. I wish to thank Dr. J. C. Barlow, Dr. C. S. Churcher, Dr. C. Eriksen and Dr. J. R. Tamsitt who read different parts of the manuscript and offered helpful suggestions. I am also grateful to Dr. J. B. Cope, Dr. H. B. Hitchcock, Dr. N. Mrosovsky, Dr. D. M. Power and Dr. D. A. Smith who provided helpful advice. To Dr. S. R. Brown, the director of the Queen's University Biological Station, I am grateful for allowing me to use the facilities there. Dr. J. B. Sparling of the Botany 
Department at the University of Toronto kindly loaned climatological equipment during the winter of 1965-66.

I am indebted to the many people who allowed me to band bats on their property: Mr. A. Cross, Mr. J. Christie, Mrs. R. Coulson, Mr. K. Simpson, the ministers of the Anglican and United Churches in Seeley's Bay and Westport, Mr. P. Ebsworth and Mr. J. Hammel of the New Calumet Mines, Mr. Tom Guiney, and the management of the McIntyre-Porcupine mine in Timmins. I am very grateful to Mr. G. Kirwin for drawing my attention to the mine at Renfrew and to the Ontario Departments of Lands and Forests and Mines for providing valuable co-operation in many ways.

Mr. Bob Webb, Mr. Jim Alcock and Mr. John McCallum assisted with the field work. Special thanks are extended to the following for giving freely of their time to assist in banding operations: Mr. J. Borack, Dr. R. E. Beschel, Miss D. Brook, Mr. J. Dick, Dr. A. Donaldson, Mr. D. Forstall, Dr. A. Fink, Mr. P. Gaskin, Mr. and Mrs. R. E. Geard, Mr. P. Geraghty, Mr. M. Goodchild, Mr. D. Gordon, Miss C. Guest, Mr. P. Hebert, Mr. R. James, Mr. K. MacGregor, Mr. N. Mainland, Mr. B. Majoribanks, Mr. T. Morris, Mr. A. Morris, Mr. and Mrs. H. Rerup, Mr. D. Rice, Mr. I. Seddon, Mr. R. Spence, Mr. R. Stefanski, Mr. J. E. Storer III, Mr. B. Thompson, Mr. H. Whyte, Mr. M. Wilcox and Dr. and Mrs. J. M. Young.

The photographs were prepared by the Photography Departments at the ROM and at Carleton University. The figures were prepared by Mrs. S. Poray at the ROM and by the Drafting Department at Carleton University. Special thanks go to Mrs. E. Fenton and the staff of the ROM Library for locating references.

The following deserve special credit for providing help and moral support during the study: Mr. J. Allan Graham, Mr. Jack G. Woods, Mr. Geoff E. Turner, the staff of the Mammalogy Department at the ROM and my wife, Eleanor.

This study was supported by the National Research Council of Canada grants awarded to Dr. R. L. Peterson and the Department of Zoology at the University of Toronto. I thank the Ontario Government and the National Research Council of Canada for awarding me funds that allowed me to conduct the research.

\section{Literature Cited}

ALDER, L.

1926 Der Winterschlaf. Hanb. Norm. Path. Physiol. vol. 17, pp. 105133 (cited by Stones and Wiebers, 1965).

BEER, J. R.

1955 Survival and movements of banded big brown bats. J. Mammal. vol. 36, pp. 242-248.

BEER, J. R. and A. G. RICHARDS

1956 Hibernation of the big brown bat. J. Mammal. vol. 37, pp. 31-41.

BENTON, A. H. and J. SHAROUN

1958 Notes on a breeding colony of Myotis. J. Mammal. vol. 39, pp. 293-295. 
BOURLIERE, F.

1952 Quelques remarques sur l'écologie comparée des primates. Biol. Méd. vol. 41, pp. 507-538.

BROSSET, A.

1961 L'hibernation chez les chiroptères tropicaux. Mammalia vol. 25, pp. 413-452.

1966 La Biologie des Chiroptères. Masson et Cie, 240 pp.

BROWN, D. M., G. A. MCKAY and L. J. CHAPMAN

1968 The climate of southern Ontario. Can. Dept. Transport, Met. Branch, Climatological Studies, No. 5, 50 pp.

CAGLE, F. R. and L. COCKRUM

1943 Notes on a summer colony of Myotis. J. Mammal. vol. 24, pp. 474-492.

COCKRUM, E. L.

1956 Homing, movements and longevity of bats. J. Mammal. vol. 37, pp. 48-57.

CHEW, R. M. and H. E. WHITE

1960 Evaporative water losses of the pallid bat. J. Mammal. vol. 41, pp. 452-458.

CHRISTIAN, J. J.

1956 The natural history of a summer aggregation of the big brown bat, Eptesicus fuscus fuscus. Am. Midl. Nat. vol. 55, pp. 66-96.

CHURCHER, C. S. and M. B. FENTON

1968 Vertebrate remains from the Dickson limestone quarry, Halton County, Ontario, Canada. Bull. Nat. Speleog. Soc. vol. 30, pp. 1116.

DAVIS, W. H.

1959 Disproportionate sex ratios in hibernating bats. J. Mammal. vol. 40, 16-19.

1966 Population dynamics of the bat Pipistrellus subflavus. J. Mammal. vol. 47, pp. 383-396.

1967 Theoretical significance of tolerance to high temperatures by Myotis lucifugus. Bat. Res. News vol. 9, p. 13.

DAVIS, W. H. and H. B. HITCHCOCK

1964 Notes on sex ratios of hibernating bats. J. Mammal. vol. 45, pp. 475-476.

1965 Biology and migration of the bat, Myotis lucifugus, in New England. J. Mammal. vol. 46, pp. 296-313.

DAVIS, W. H., R. W. BARBOUR and M. D. HASSEL

1968 Colonial behavior of Eptesicus fuscus. J. Mammal. vol. 49, pp. 4450.

DeBLASE, A. F., S. R. HUMPHREY and K. S. DRURY

1965 Cave flooding and mortality in bats in Wind Cave, Kentucky. J. Mammal. vol. 46, pp. 96.

DOWNING, s. C. and D. H. BALDWIN

1961 Sharp-shinned Hawk preys on red bat. J. Mammal. vol. 42, pp. 540. DULIC, B.

1959 Influence du microclimat ambiant sur le sommeil hivernal des Chiroptères dans quelques régions Mediterranéenes. Proc. Int. Cong. Zool. vol. 15, pp. 815-816. 
EISENTRAUT, M.

1934 Der Winterschlaf der Fledermäus mit besonderer Berücksichtigung der Wärmeregulation. Z. Morph. Ökol. Tiere Berlin, vol. 29, pp. 231-267.

1936 Ergebnisse der Fledermäusberingung nach dreijahriger. Versuchszeit Z. Morphol. Ökol. vol. 31, pp. 1-26.

1938 Wärmeregulation tropischer Fledermäus. Sitzungsber d. ges. naturforsh, Freunde, pp. 86-90.

1960 Heat regulation in primitive mammals and in tropical species. Bull. Mus. Comp. Zool. Harvard, vol. 124, pp. 31-43.

FENTON, M. B.

1966a Parturition, growth and milk dentition of the bat, Myotis lucifugus lucifugus (LeConte), in southeastern Ontario. M.Sc. thesis, Dept. Zool. Univ. of Toronto, $52 \mathrm{pp}$.

1966b Myotis sodalis in caves near Watertown, New York. J. Mammal. vol. 47 , pp. 526.

1969a The carrying of young by females of three species of bats. Can. J. Zool. vol. 47, pp. 158-159.

1969b Summer activity of Myotis lucifugus (Chiroptera: Vespertilionidae) at hibernacula in Ontario and Quebec. Can. J. Zool. vol. 47, pp. 597-602.

1969c Ecological studies of bats in Ontario and adjacent regions. Ph.D. thesis, Dept. Zool. Univ. of Toronto, 148 pp.

FISHER, K. C. and J. F. MANERY

1967 Water and electrolyte metabolism in heterotherms. International Symposium on Natural Mammalian Hibernation 1965; Mammalian Hibernation III, proceedings, Edinburgh and London, Oliver and Boyd, pp. 235-279.

GAISLER, J.

1966 A tentative ecological classification of colonies of European bats.

Lynx vol. 6, pp. 35-39.

GIFFORD, C. E. and D. R. GRIFFIN

1960 Notes on homing and migratory behavior of bats. Ecology, vol. 41, pp. 378-381.

GOULD, E.

1955 The feeding efficiency of insectivorous bats. J. Mammal. vol. 36, pp. 399-407.

GRIFFIN, D. R.

1940 Migrations of New England bats. Bull. Mus. Comp. Zool. Harvard, vol. 86 , pp. $217-246$.

1945 Travels of banded cave bats. J. Mammal. vol. 26, pp. 15-23.

GREENHALL, A. M. and J. L. PARADISO

1968 Bats and bat banding. Bureau of Sport Fisheries and Wildlife Resource Pub. 72, 47 pp.

GUTHRIE, M.

1933 Notes on the seasonal movements and habits of some cave bats. J.

Mammal. vol. 14, pp. 1-19.

HALL, J. S

1962 A life history and taxonomic study of the Indiana bat, Myotis sodalis. Reading Pub. Mus. and Art Gallery, Reading, Pa. Sci. Pub. no. 12, pp. 1-68. 
HALL, J. S. and F. J. BRENNER

1968 Summer netting of bats at a cave in Pennsylvania. J. Mammal. vol. 49, pp. 779-781.

HANUS, $\mathrm{K}$.

1959 Body temperatures and metabolism in bats at different environmental temperatures. Physiol. Bohemoslov. vol. 8, pp. 250-259 (cited by Stones and Wiebers, 1965).

HENSHAW, R. E. and G. E. FOLK

1966 Relation of thermoregulation to seasonally changing microclimate in two species of bats (Myotis lucifugus and M. sodalis). Physiol. Zool. vol. 39, pp. 223-236.

HERREID, C. F.

1963a Survival of a migratory bat at different temperatures. J. Mammal. vol. 44, pp. 431-433.

1963b Metabolism of the Mexican free-tailed bat. J. Cell. Comp. Physiol. vol. 61, pp. 201-207.

HERREID, C. F. and K. SCHMIDT-NIELSON

1966 Oxygen consumption, temperature and water loss in bats from different environments. Am. J. Physiol. vol. 211, pp. 1108-1112.

HITCHCOCK, H. B.

1949 Hibernation of bats in southeastern Ontario and adjacent Quebec. Canad. Field Nat. vol. 63, pp. 47-59.

1950 Sex ratios in hibernating bats. Bull. Nat. Speleog. Soc. vol. 12, pp. 26-28.

1965 Twenty-three years of bat banding in Ontario and Quebec. Canad. Field Nat. vol. 79, pp. 4-14.

HOCK, R. J.

1951 The metabolic rates and body temperatures of bats. Biol. Bull. vol. 101, pp. 289-299.

HUMPHREY, S. and J. B. COPE

1964 Movements of Myotis lucifugus from a colony in Boone County, Indiana. Proc. Ind. Acad. Sci. vol. 72, pp. 268-271.

JOHNSON, G. E.

1931 Hibernation in mammals. Quart. Rev. Biol. vol. 6, pp. 439-461. JONES, C.

1967 Growth, development and wing loading in the evening bat, Nycticeius humeralis (Rafinesque). J. Mammal. vol. 48, pp. 1-19.

KALLEN, F. C.

1964 Some aspects of water balance in the hibernating bat. Ann. Acad. Sci. Fenn. (Ser. A, IV) vol. 71, pp. 257-267.

KALLEN, F. C. and H. A. KANTHOR

1967 Urine production in the hibernating bat. Symposium on Natural Mammalian Hibernation, 1965; Mammalian Hibernation III, proceedings, Edinburgh and London, Oliver and Boyd, pp. 280-294.

KAYSER, C.

1939 Les échanges respiratoires des hibernants rèveilles. Ann. Physiol. vol. 15, pp. 1087-1219.

1940 Les échanges respiratoires des hibernants à l'état de sommeil hivernal. Ann. Physiol. vol. 16, pp. 127-221.

1950 La léthargie hivernales des mammiféres et la mécanism de sa genese. Mammalia vol. 14, pp. 105-125. 
KAYSER, C.

1957 Le sommeil hivernal, problème de thermorégulation. Rev. Canad. Biol. vol. 16, pp. 303-389.

1961 The physiology of natural hibernation. Pergammon Press, New York.

1965 Hibernation. In Mayer, W. V. and R. G. van Gelder, eds., Physiological Mammalogy, New York and London, Academic Press, vol. 2, pp. 180-278.

KLEIMAN, D. G.

1969 Maternal care, growth rate and development in the noctule (Nyctalus noctula), pipistrelle (Pipistrellus pipistrellus) and serotine (Eptesicus serotinus) bats. J. Zool. Lond. vol. 157, pp. 187-211.

LIGHT, P. and P. LEITNER

1967 Behavioral responses to high temperatures in three species of California bats. J. Mammal. vol. 48, pp. 52-61.

MANVILLE, R. $\mathbf{H}$.

1963 Accidental mortality in bats. Mammalia vol. 27, pp. 361-365.

MENAKER, M.

1961 The free running period of the bat clock: seasonal variations at low body temperature. J. Cell. Comp. Physiol. vol. 57, pp. 81-86.

1962 Hibernation-hypothermia: an annual cycle of response to low temperature in the bat, Myotis lucifugus. J. Cell. Comp. Physiol. vol. 59, pp. 163-173.

1964 Frequency of spontaneous arousal from hibernation in bats. Nature vol. 203, pp. 540-541.

MOHR, C. E.

1932 The seasonal distribution of bats in Pennsylvania. Proc. Penna. Acad. Sci. vol. 6, pp. 1-16.

1945 Sex ratios of bats in Pennsylvania. Proc. Penna. Acad. Sci. vol. 19, MÖHRES, F. P. pp. 65-69.

1967 Communicative character of some sonar signals in bats. In Les systèmes sonars animaux, biologique et bionique, ed. R. G. Busnel. MUMFORD, R. E.

Nato Advanced Study Institute, pp. 939-948.

1958 Population turnover in wintering bats in Indiana. J. Mammal. vol. 39, pp. 253-261.

MUMFORD, R. E. and J. B. COPE

1964 Distribution and status of the Chiroptera of Indiana. Am. Midl. Nat. vol. 72, pp. 473-489.

PEARSON, O. P., M. R. KOFORD and A. K. PEARSON

1952 Reproduction of the lump-nosed bat, Corynorhinus rafinesquii in California. J. Mammal. vol. 33, pp. 272-320.

PETERSON, R. L.

1966 The mammals of eastern Canada. Toronto, Oxford Univ. Press, $465 \mathrm{pp}$.

PHILLIPS, G. L.

1966 Ecology of the big brown bat (Chiroptera: Vespertilionidae) in northeastern Kansas. Am. Midl. Nat. vol. 75, pp. 168-198.

PIRLOT, P.

1946 Hibernation of bats; resistance to desiccation. Thesis prepared as partial fulfillment of requirements for a licence in Science. Univ. 
of Louvain. Translated from the French by the Hibernation Information Exchange, 25 pp.

RACEY, P. A.

1969 Diagnosis of pregnancy and experimental extension of gestation in the pipistrelle bat, Pipistrellus pipistrellus. J. Reprod. Fert. vol. 19 , pp. 465-474.

REITE, O. B. and W. H. DAVIS

1966 Thermoregulation in bats exposed to low ambient temperatures. Proc. Soc. Eptl. Biol. Med. vol. 121, pp. 1212-1215.

RUST, C. C.

1962 Temperature as a modifying factor in the spring pelage change of short-tailed weasels. J. Mammal. vol. 43, pp. 323-328.

RYSGAARD, G. W.

1942 A study of the cave bats of Minnesota with special reference to the large brown bat, Eptesicus fuscus (Beauvois). Am. Midl. Nat. vol. 28, pp. 245-267.

SHERMAN, H. B.

1939 Birth of the young of Myotis autsroriparius. J. Mammal. vol. 11, pp. 495-503.

SISK, M. 0.

1957 A study of the sudoriparous glands of the little brown bat, Myotis lucifugus lucifugus. J. Morph. vol. 101, pp. 425-455.

SMITH, E.

1954 Studies on the life history of non-cave-dwelling bats in northwestern Ohio. Ohio J. Sci. vol. 54, pp. 1-12.

SNYDER, L. L.

1947 The hawks and owls of Ontario. R. Ont. Mus. Zool. Handb. no. 2, $47 \mathrm{pp}$.

SOAVE, O. A.

1966 The transmission of rabies to mice by ingestion of infected tissue.

Am. J. Vet. Res. vol. 27: pp. 44-46.

STONES, R. C. and J. E. WIEBERS

1965 A review of temperature regulation in bats (Chiroptera). Am. Midl. Nat. vol. 74, pp. 155-167.

1967 Temperature regulation in the little brown bat, Myotis lucifugus. International Symposium on Natural Mammalian Hibernation, 1965, Mammalian Hibernation III, Proceedings, Edinburgh and London, Oliver and Boyd, pp. 97-109.

STUDIER, E. H., J. W. PROCTER and D. J. HOWELL

1970 Diurnal weight loss and tolerance of weight loss in five species of Myotis. J. Mammal. vol. 51, pp. 302-309.

TINKLE, D. W. and I. G. PATTERSON

1965 A study of hibernating populations of Myotis velifer in northwestern Texas. J. Mammal. vol. 46, pp. 612-633.

TWENTE, J. W., JR.

1955a Some aspects of habitat selection and the behaviour of caverndwelling bats. Ecology vol. 36, pp. 706-732.

$1955 \mathrm{~b}$ Aspects of a population study of cavern-dwelling bats. J. Mammal. vol. 36, pp. 379-390.

TWENTE, J. W., JR. and J. A. TWENTE

1964 A hypothesis concerning the evolution of heterothermy in bats. Ann. Acad. Sci. Fenn. (Ser. A, IV) vol. 71, pp. 433-442. 
WALKER, E. P.

1964 Mammals of the world, Volume I. Baltimore, Johns Hopkins Press, 646 pp.

WATSON, A.

1965 Observing the natural behaviour of bats in flight, experiences in Britain and Finland. Stud. in Speleog. vol. 1, pp. 100-104.

WIMSATT, W. A.

1945 Notes on breeding behavior, pregnancy and parturition in some vespertilionid bats of the eastern United States. J. Mammal. vol. 26, pp. 23-33.

1969 Transient behavior, nocturnal activity patterns and feeding efficiency of vampire bats (Desmodus rotundus) under natural conditions. J. Mammal. vol. 50, pp. 233-244. 
. 


